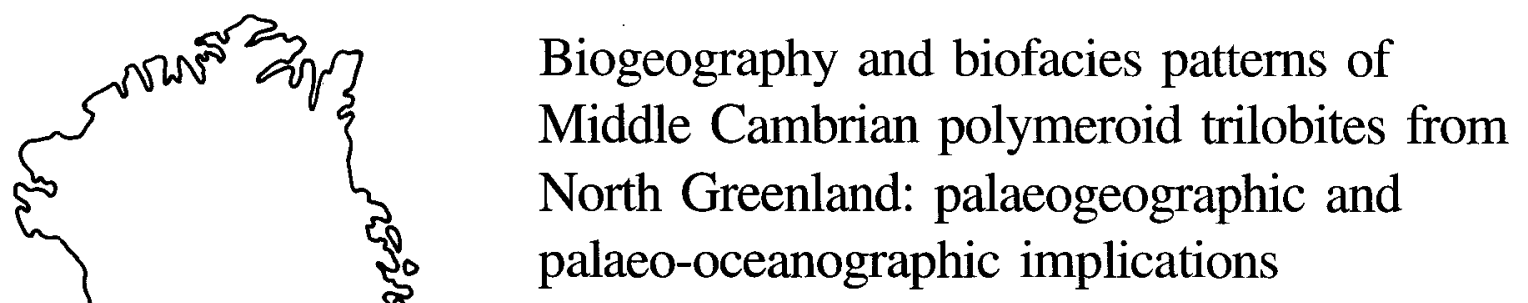

Loren E. Babcock

\begin{abstract}
Fossils from Middle Cambrian rocks of Peary Land and Nyeboe Land, North Greenland, show that polymeroid trilobite biofacies were strongly segregated near the shelf margin of Laurentia. Some biofacies include trilobites of Laurentian aspect that lived in warm, relatively shallow water, and other biofacies have trilobites of Baltic aspect that lived in cool, deeper water. Polymeroids in the Glossopleura and Ptychagnostus gibbus zones are from open-shelf lithofacies and are mostly of Laurentian aspect. Polymeroids in the Lejopyge laevigata Zone are from deep, outermost shelf to upper slope lithofacies and are entirely of Baltic aspect. Polymeroids in the Ptychagnostus atavus Zone are from an intermediate, outer-shelf setting and are of mixed Laurentian and Baltic aspect. Mixing of polymeroids from different biofacies is inferred to have occurred through downslope movement by localised sediment gravity flows. The presence of segregated trilobite biofacies at the shelf margin of Laurentia is the first evidence for a thermocline in marine waters surrounding Laurentia during the Middle Cambrian, although evidence for a thermocline during the Early and Late Cambrian has been reported previously.

The presence of polymeroids of Baltic aspect in Laurentian rocks of North Greenland has important implications for the analysis of tectonostratigraphic terranes. The presence of cool-water trilobites is not sufficient evidence to conclude that the terrane originated in high palaeolatitudes. Identification of an autochthonous terrane of a continental margin is possible, however, on the basis of fossil assemblages containing mixed biofacies representatives. Provenance identification is possible because the assemblages are expected to include taxa characteristic of warm-water cratonic areas along which the terrane originated.
\end{abstract}

L. E. B., Department of Geological Sciences and Byrd Polar Research Center, The Ohio State University, Columbus, Ohio 43210, U.S.A.

Historically, Cambrian trilobite faunas from the circum-Atlantic region have been assigned to either an Atlantic or Pacific faunal province. These provinces have also been called Acado-Baltic and North American, respectively. Several biogeographical studies (e.g., Lochman-Balk \& Wilson, 1958; Palmer, 1969, 1972, 1979; Cowie, 1971, 1974; Theokritoff, 1979, 1985; Shergold, 1988) have shown that the Pacific province is characterised by polymeroid trilobites that were mostly endemic to the shelf of Laurentia, whereas the Atlantic province is characterised by polymeroids that were first described from localities in Scandinavia, southern Great Britain, Maritime Canada, or New England.

Trilobites of the Atlantic province have been important in studies of early Palaeozoic biostratigraphy and palaeogeography. Zonations developed for Middle Cambrian trilobites worldwide are commonly compared to the zo- nation of Sweden's trilobites (Westergård, 1946, 1953). Information about trilobite biogeography is also routinely used to supplement palaeomagnetic, stratigraphic, structural, or other geologic evidence about the configuration and history of continents and oceans during the early Palaeozoic.

The biogeography of Cambrian trilobites has been central to some arguments concerning the origin of tectonostratigraphic terranes in the Appalachian Orogen (see Keppie, 1989 and Horton et al., 1989 for definitions of terranes). The presence of polymeroids having Atlantic affinities in rocks of Maritime Canada and New England (e.g., Howell, 1925; Hutchinson, 1952, 1962; Poulsen \& Anderson, 1975; Bergström \& Levi-Setti, 1978) has been used to infer the exotic origin of these terranes and subsequent accretion to North America during the middle or late Palaeozoic (see Williams \& Hatcher, 1982; Secor 


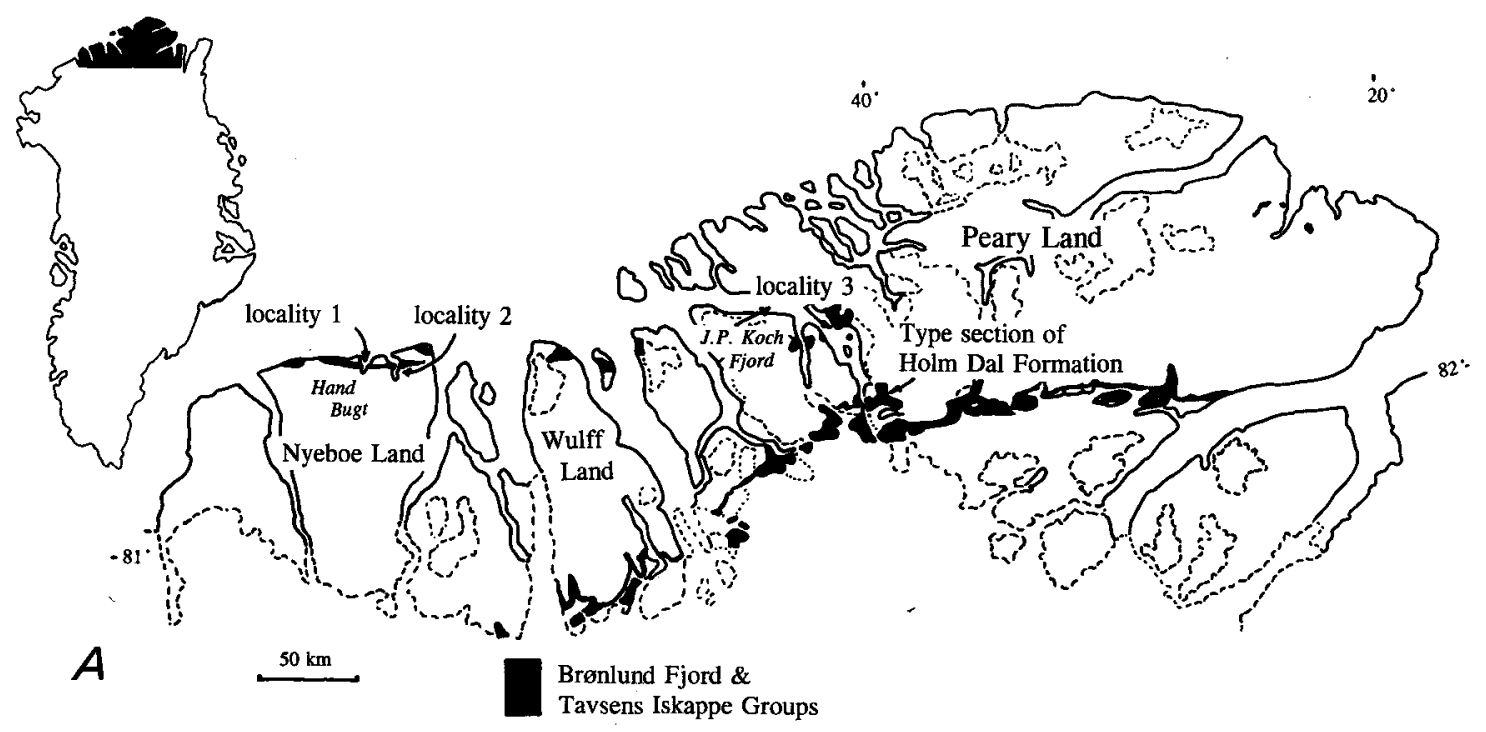

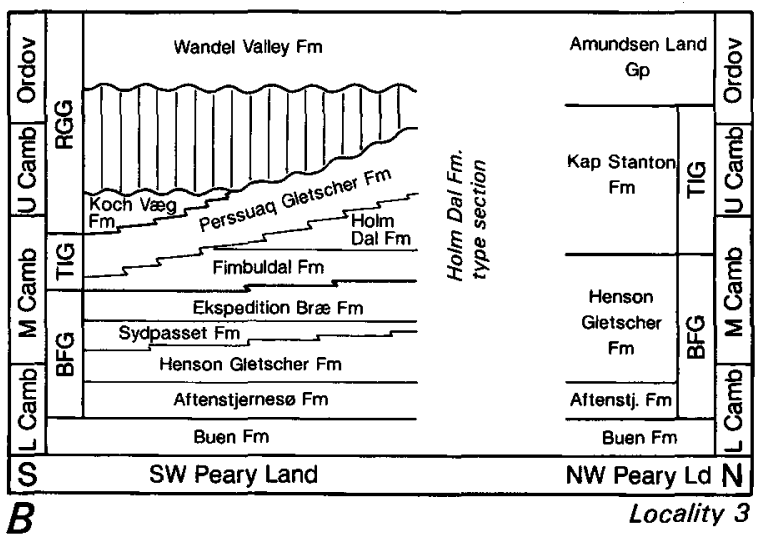

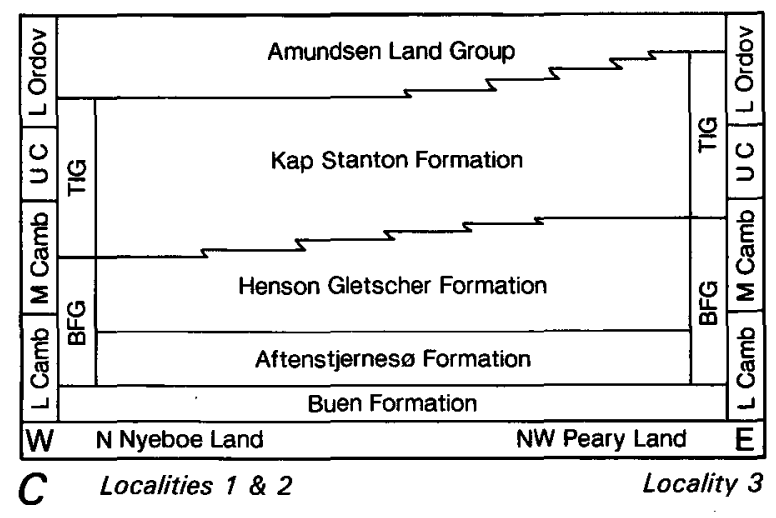

Fig. 1. Derivation of fossiliferous samples. A, map showing the distribution of the Brønlund Fjord and Tavsens Iskappe Groups in North Greenland and collection localities discussed in the text. B, C, geological crosssections through Cambrian - Lower Ordovician strata in North Greenland. BFG, Brønlund Fjord Group; TIG, Tavsens Iskappe Group; RGG, Ryder Gletscher Group (from Ineson et al., 1994). D, biostratigraphy of fossiliferous samples (stars) discussed in the text. 
et al., 1983; Gromet, 1989; Keppie, 1989). Although not all examples of Atlantic trilobites in North America have been associated with accreted terranes, common practice has been to suspect an exotic origin for a terrane that contains such a fauna (see Secor et al., 1983; Gromet, 1989; Horton et al., 1989; Samson et al., 1990), particularly if structural and stratigraphic evidence suggests that it was previously decoupled from North American shelf rocks.

This paper documents the biogeographic and biofacies distributions of polymeroid trilobites from Middle Cambrian rocks of the Henson Gletscher and Kap Stanton formations of Nyeboe Land and Peary Land, North Greenland (Fig. 1). Systematic descriptions are given in an accompanying paper (Babcock, 1994). An additional accompanying paper by Robison (1994) describes agnostoid trilobites from the same formations. The newly described faunas are preserved in open-shelf to deep outermost shelf or upper slope? lithofacies; the palaeogeographic setting is described in a third accompanying paper by Ineson et al. (1994). The Henson Gletscher and Kap Stanton formations are coeval in part with the Holm Dal Formation (Peel, 1988), and were in close palaeogeographic proximity (Fig. 1). The Holm Dal Formation contains polymeroid genera that are characteristic of open-shelf environments of Laurentia (Robison, 1988). Middle Cambrian strata in relevant parts of Nyeboe Land and Peary Land are relatively undisturbed structurally, and lithostratigraphic correlations in the region have been made with a high degree of confidence over scores of kilometres (J. S. Peel, personal communication, 1988; cf. Higgins et al., 1991). Fossiliferous localities (Fig. 1) are in native terranes, as defined by Keppie (1989), of the Laurentian palacocontinent.

The faunas from the Henson Gletscher, Kap Stanton, and Holm Dal formations provide an opportunity to compare open-shelf faunas with those of nearby, deeper marine environments along the Innuitian margin of Laurentia. Sharp biofacies differences between open-shelf lithofacies and deep outermost shelf lithofacies are interpreted to result from differences in either water temperature or environments that covary with temperature. Polymeroids of Laurentian aspect were present in warm shelf waters, whereas polymeroids of Baltic aspect were present in deeper, cool waters.

\section{Biogeographic terminology}

The terms Atlantic (or Acado-Baltic) and Pacific (or North American) previously have been used both for the geographic origins of Cambrian trilobite faunas and for faunal provinces. Boundaries of the faunal provinces do not always agree with the boundaries of tectonic plates as presently understood. The terms Pacific and North American, for example, have been used for trilobites or faunas typical of shelf lithofacies of North America as well as Greenland and other regions. The terms Atlantic and Acado-Baltic have been used for trilobites or faunas first described from Scandinavia, Britain, or parts of eastern North America. Similar trilobites, however, also have been found in such other regions as Siberia, Australia, and Antarctica. Poulsen (1969) even applied the term 'Atlantic' to sparse agnostoid assemblages from North Greenland.

To reduce ambiguity, I use separate terms for the geographic origin of a fauna and its aspect. The geographic origin of a fauna is simply the geographic or palaeogeographic locality from which the fauna was collected. The aspect of a fauna refers to a recognised geographic or palaeogeographic region with which an assemblage of taxa is most characteristically associated. It is not necessarily equivalent to a faunal province as previously interpreted. Both types of terms are derived from recognised geographic or palaeogeographic names. The aspect of a fauna, although it bears the name of a geographic region, is recognised as an entity separate from any geographic region. As an example, a fauna collected from Laurentia is a Laurentian fauna, but it may contain taxa of Laurentian, Baltic, Gondwanan, or other aspect.

\section{Palaeogeography and biogeography}

Current palaeogeographic reconstructions (e.g., Scotese, 1987; Scotese \& McKerrow, 1990) show the Cambrian world as comprising four principal cratonic areas, Laurentia, Baltica, Gondwana, and Siberia, as well as other smaller tectonic plates (Fig. 2). Terminology and definitions of tectonic plates used in this paper generally follow those of Scotese et al. (1979). Exceptions are England, Acadia, and Armorica, which are defined according to Young (1986).

Laurentia included cratonic North America, Greenland, western Newfoundland, northern Ireland and Scotland, Spitsbergen, western Norway, and the Chukotsk Peninsula of eastern Siberia. During the Cambrian, Laurentia was in tropical latitudes. At times, extensive carbonate platforms developed in surrounding warm, shallow seas. Development of the platforms led to marked differentiation of trilobite faunas in restricted-shelf and open-shelf habitats (e.g., Palmer, 1972, 1973; Robison, 1976).

Siberia, which consisted of the present-day Siberian platform, Mongolia, Manchuria, and Taymyr, was also in low latitudes during the Cambrian. It too was the site of carbonate-platform development during parts of the Cambrian. 

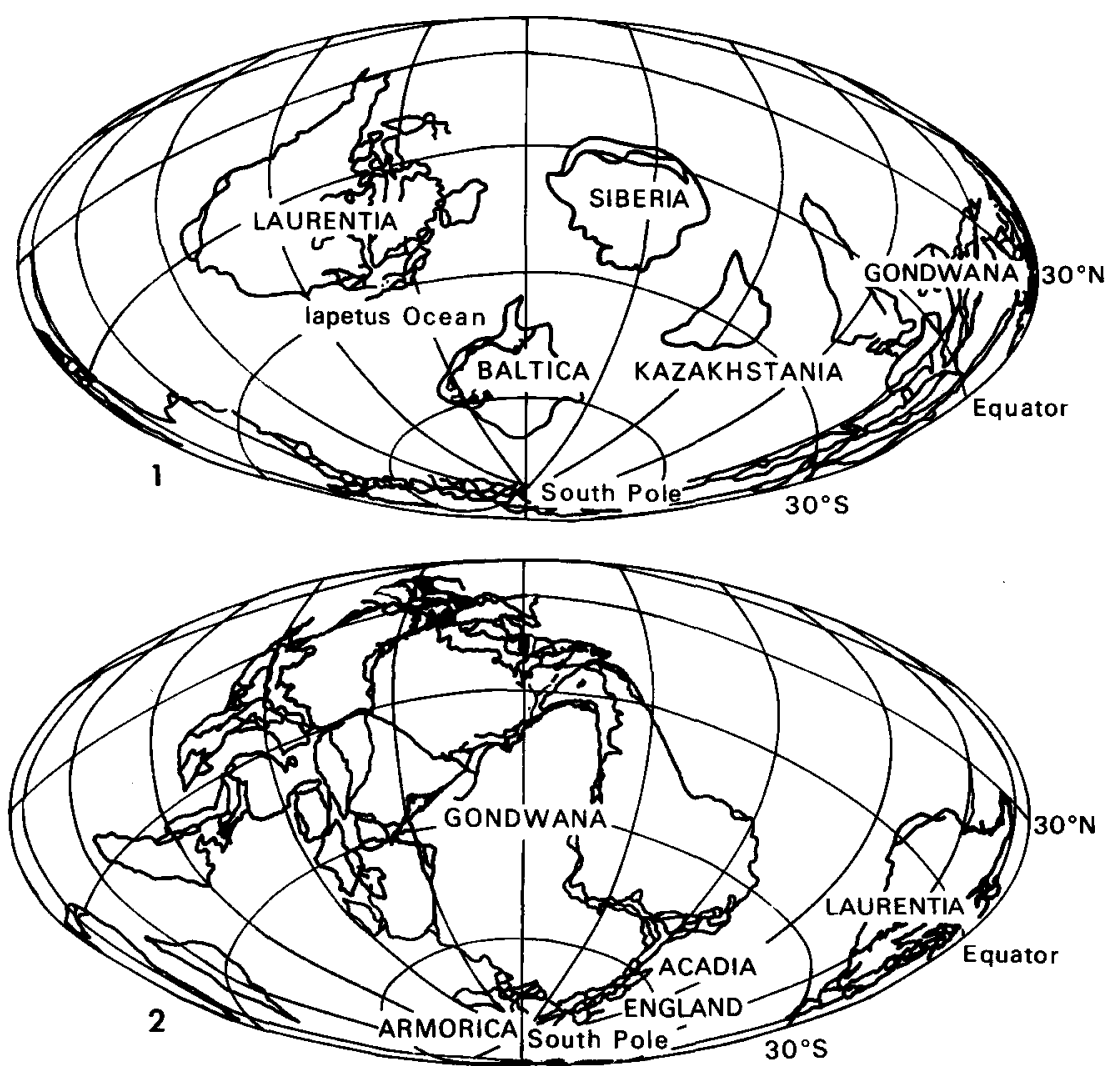

Fig. 2. Maps of reconstructed Middle Cambrian paleogeography (after Scotese \& Denham, 1988). Outlines of present-day geographic areas are included for reference. The view is from 30 degrees south latitude. 1, View emphasising the relationships of Laurentia, Baltica, and Siberia. 2, View emphasising Gondwana and the peri-Gondwanan terranes.
Baltica, which consisted of north-western Europe exclusive of the British Isles and western Norway, was probably in moderately high to high southern latitudes during most of the Cambrian (Scotese et al., 1979; Scotese, 1987; Scotese \& McKerrow, 1990; Torsvik et al., 1991; but see Smith et al., 1981). Shelf sedimentation was dominated by fine-grained siliciclastics, including alum shales. Carbonate units comprise a minor part of the Cambrian section.

Major components of Gondwana were South America, Africa, Florida, Arabia, Turkey, Iran, Afghanistan, India, Madagascar, Australia, and parts of Antarctica. Gondwana extended from tropical to polar latitudes. England (Wales, southern Ireland, and southern England), Acadia (eastern New England and Maritime Canada except for eastern Nova Scotia and western Newfoundland), and Armorica (Bohemia, southern Germany, France, Iberian Peninsula, northern Morocco, and eastern Nova Scotia) were three important peri-Gondwanan terranes. All were located in polar or subpolar latitudes of the North African sector of Gondwana.

Other important terranes include those of Kazakhstania (including present-day Kazakhstan, Tien Shan, and the Aral Sea area) and present-day China. Recent evidence suggests that Kazakhstania is composed of several fused microcontinental blocks, and includes an archipelago located in low palaeolatitudes (Cook \& Taylor, 1989; Cook et al., 1991). Considerable uncertainty remains concerning the palaeogeographic positions of tectonostratigraphic terranes of China.

A variety of geophysical, stratigraphic, structural, petrologic, and palaeontologic evidence has been used to assess plate-tectonic history. Faunal evidence is of particular importance in the lower Palaeozoic because other reliable geologic and geophysical evidence can be more difficult to obtain than for other intervals of the Phanerozoic. Distributions of fossils played a major role in Wilson's (1966) hypothesis of a proto-Atlantic Ocean, as well as in many subsequent studies of the history of the Iapetus Ocean. Distributional data continue to be important in current arguments about the definition and history of terranes in the circum-Atlantic region (e.g., Williams \& Hatcher, 1982; Secor et al., 1983; Samson et al., 1990) and elsewhere.

Studies of the distribution of Cambrian trilobites worldwide (e.g., Palmer, 1969, 1972, 1979; Jell, 1974; Burrett \& Richardson, 1980; Shergold, 1988; Robison, 1991) have demonstrated that shelf seas of the major cratonic areas of Laurentia, Baltica, Siberia, and Gondwana tended to have relatively large numbers of endemic 
trilobite genera and species. Endemism is strongest among polymeroids, most of which were probably benthic. Most genera and many species of the largely pelagic agnostoids had cosmopolitan distributions in world oceans (e.g., Robison, 1972, 1984, 1988; Öpik, 1979).

Patterns of distribution of early Palaeozoic trilobites in the circum-Atlantic region have traditionally been used to define Atlantic (or Acado-Baltic) and Pacific (or North American) faunal provinces (e.g., Palmer, 1969, 1972; Poulsen, 1969; Cowie, 1971, 1974). Biotic exchange between these regions has been generally thought to have been limited by several factors, including the time available for larval migration across geographic distances (McKerrow \& Cocks, 1976; Burrett \& Richardson, 1980; Fortey \& Cocks, 1986). In this interpretation, Iapetus may have been wide during the Cambrian (Conway Morris \& Rushton, 1988). A trend of increasing similarity between North American and western European faunas during the Ordovician and Silurian has been inferred to result from the progressive closure of Iapetus and the elimination of faunal barriers (McKerrow \& Cocks, 1976).

Studies of distributional patterns in the circum-Atlantic region, like most that have used biogeographic data to help determine the configuration of plates during the early Palaeozoic, have incorporated three major assumptions (Taylor \& Forester, 1979). First, faunal elements were assumed to have been largely restricted to shallowshelf seas of single continental blocks. Second, the shallow-shelf seas were surrounded by deeper oceans, which inhibited dispersal. Third, the degree of faunal dissimilarity between areas is assumed to have been a function of their past geographic separation (also see Sneath \& McKenzie, 1973). Mounting evidence from the distributions of trilobites (Palmer, 1973; Fortey, 1975; Taylor, 1976, 1977; Cook \& Taylor, 1975; Taylor \& Cook, 1976; Ludvigsen, 1978; Taylor \& Forester, 1979; Babcock \& Robison, 1989; Robison \& Babcock, 1990) and other organisms (Skevington, 1974; Sweet and Bergström, 1974; Barnes \& Fåhraeus, 1975; Bergström \& Carnes, 1976; Bergström, 1977; Fortey \& Cocks, 1986) indicates that these assumptions are not always valid. Factors of the marine environment other than distance have probably had an important influence on the degree of faunal resemblance between geographic regions. Such factors may include latitudinal climatic gradients (e.g., Ekman, 1953; Valentine, 1973) and differences between shelf seas and the deep sea (e.g., Hedgpeth, 1957; Bruun, 1957; Menzies et al., 1973; Benson, 1975, 1988; Taylor, 1977). The effects of both of these factors on faunal distributions have been disregarded or accorded minor importance in many studies of early Palaeozoic faunas. Also, they have often been disregarded when synthesising geological and geophysical data for palaeogeographic reconstructions.

\section{Biogeographic affinities of North Greenland polymeroid trilobites}

Middle Cambrian rocks of North Greenland contain polymeroid trilobite assemblages of both Laurentian and Baltic aspect. Most polymeroids described by Poulsen (1927), Poulsen (1964), Palmer \& Peel (1981), and Robison (1988) have closest affinities with trilobites that are characteristic of open-shelf areas of Laurentia. Polymeroids identified by Poulsen (1969) from Nyeboe Land, including Eodiscus punctatus and a paradoxidid (possibly Centropleura) have closest affinities with taxa characteristic of cratonic areas of Baltica. The observed geographic distributions of polymeroid taxa identified from the Henson Gletscher and Kap Stanton formations are summarised in Tables 1 to 4 .

All genera in new Geological Survey of Greenland (GGU) collections (Babcock, 1994, but see also a preliminary notice by Fletcher et al., 1988) from the Glossopleura Zone (Table 1) are widely distributed in openshelf lithofacies of Laurentia. One genus, Kootenia, is also known from shelf lithofacies of present-day Asia and Australia. Two species, Ogygopsis klotzi and Glossopleura walcotti, have been recognised elsewhere in Laurentia.

In addition to its occurrence in North Greenland, $O$. klotzi is known from the Stephen Formation of British Columbia (Rasetti, 1951), the Metalline Formation of Washington (McLaughlin \& Enbysk, 1950), the Miller Mountain Formation of Nevada (Nelson, 1963), the Cow Head boulders of western Newfoundland (Young \& Lud-

\section{Table 1. Distributions of polymeroid genera in the Glossopleura Zone of the Henson Gletscher Formation}

\begin{tabular}{lcccccc}
\hline TAXA & AN & AM & GB & AL & CR & OL \\
\hline Glossopleura walcotti & - & - & s & - & G & - \\
Kootenia nodosa & G & G & G & G & G & G \\
Ogygopsis klotzi & s & s & s & G & s & - \\
Syspacephalus sp. 3 & G & G & G & - & G & - \\
\hline
\end{tabular}

Observed geographic distributions of polymeroid genera $(\mathrm{G})$ or genera and species (s) identified in the Glossopleura Zone of the Henson Gletscher Formation (hyphen indicates absence of a genus). Abbreviations of geographic regions are AN, northern Appalachia (western Newfoundland and Quebec); AM, middle Appalachia (New York and Pennsylvania); GB, Great Basin (Utah, Nevada, and California); AL, east-central Alaska; CR, Canadian Rocky Mountains; and OL, tectonic blocks other than Laurentia. 
Table 2. Distributions of polymeroid genera in the Ptychagnostus gibbus Zone of the Henson Gletscher Formation

\begin{tabular}{lcccccc}
\hline TAXA & AN & AM & GB & AL & CR & OL \\
\hline Bathyuriscus sp. & G & G & G & G & G & - \\
Bolaspidella sp. & - & G & G & G & - & G \\
Olenoides sp. & G & G & G & - & G & G \\
Syspacephalus sp. 2 & G & G & G & - & G & - \\
Zacanthoides sp. & G & G & G & G & G & - \\
\hline
\end{tabular}

Observed geographic distributions of polymeroid genera (G) identified in the Ptychagnostus gibbus Zone of the Henson Gletscher Formation (hyphen indicates absence of a genus). Abbreviations of geographic regions are AN, northern Appalachia (western Newfoundland and Quebec); AM, middle Appalachia (New York and Vermont); GB, Great Basin (Utah, Nevada, and California); AL, east-central Alaska; CR, Canadian Rocky Mountains; and OL, tectonic blocks other than Laurentia.

vigsen, 1989), and the Kinzers Formation of Pennsylvania (Campbell, 1971). Each occurrence represents an open-shelf setting near the ocean-facing side of a carbonate platform. Other occurrences of Ogygopsis (Nelson, 1963; Palmer \& Halley, 1979) indicate that the genus is most commonly associated with platform-edge environments (Palmer \& Halley, 1979).

G. walcotti was first described from the Cape Wood Formation of Inglefield Land, North-West Greenland. Later, abundant material was reported from the Carrara Formation of Nevada and California (Palmer \& Halley, 1979). Glossopleura was previously identified primarily from restricted-shelf lithofacies (e.g., Robison, 1976; Palmer \& Halley, 1979), but examination of collections at the University of Kansas and the U.S. National Museum of Natural History indicates that some species were more eurytopic than previously thought. In the Henson Gletscher Formation, G. walcotti is associated with such characteristic open-shelf taxa as Ogygopsis and Syspacephalus. Kootenia, with which it is also associated, is eurytopic (Robison, 1976).

Genera of polymeroids in GGU collection 298970 from the Ptychagnostus gibbus Zone have strongest affinities with genera from open-shelf environments of Laurentia (Table 2). Syspacephalus and Zacanthoides are known only from Laurentia. Bolaspidella is known with certainty from Laurentia (Robison, 1988) and the Precordillera terrane of Mendoza, Argentina (Poulsen, 1960). The Precordillera terrane may have been derived from Laurentia (Ramos et al., 1986; Robison, 1991). The reported occurrence of Bolaspidella from Kashmir (Shah \& Sudan, 1982) is probably in error (Robison, 1988). Except for Zacanthoides, which is eurytopic, all the genera are most commonly associated with open-shelf lithofacies. Olenoides inhabited open-shelf sites in Laurentia but was also present in Siberia, Kazakhstania, and Gondwana. Kootenia is a eurytopic genus that is common in Laurentia, but like some other dorypygids, it was rather widely distributed in low palaeolatitudes. Finally, Eodiscus was widespread in open-shelf settings around much of the world. Functional analyses of morphology and wide geographic distributions indicate that most eodiscids were pelagic or perhaps planktonic (Jell, 1975).

Table 3. Distributions of polymeroid genera in the Ptychagnostus atavus Zone of the Henson Gletscher and Kap Stanton formations

\begin{tabular}{|c|c|c|c|c|c|c|c|c|c|c|}
\hline TAXA & $\mathrm{AN}$ & $\mathrm{AM}$ & GB & $\mathrm{CR}$ & AL & $\mathrm{CM}$ & $\mathrm{SW}$ & EN & SP & $\mathrm{AU}$ \\
\hline Bathyuriscus concavus & G & $\mathrm{G}$ & $\mathrm{G}$ & G & G & - & - & - & - & - \\
\hline Corynexochus? sp. & - & - & - & - & $\mathrm{G}$ & - & $\mathrm{G}$ & G & - & - \\
\hline Costadiscus minutus & - & - & - & - & - & - & - & - & - & - \\
\hline Dasometopus groenlandicus & - & - & - & - & - & - & $\mathrm{G}$ & - & $\mathrm{G}$ & - \\
\hline Eodiscus scanicus & - & - & - & - & - & s & $\mathrm{s}$ & s & - & - \\
\hline Hartshillia inflata & - & - & - & - & - & $\mathrm{G}$ & - & s & $\mathrm{G}$ & - \\
\hline Olenoides cf. $O$. convexus & $\mathrm{s}$ & G & $\mathrm{G}$ & $\mathrm{G}$ & - & - & - & - & $\mathrm{G}$ & - \\
\hline Opsidiscus longispinus & - & - & - & - & - & - & $\mathrm{G}$ & - & - & G \\
\hline Parasolenopleura aculeata & - & - & - & - & - & - & $\mathrm{s}$ & $\mathrm{G}$ & - & - \\
\hline Solenopleurella transversa? & - & $\mathrm{s}$ & - & - & - & $\mathrm{G} ?$ & $\mathrm{G}$ & G? & - & - \\
\hline Syspacephalus sp. 1 & G & $\mathrm{G}$ & G & G & - & - & - & - & - & - \\
\hline
\end{tabular}

Observed geographic distributions of polymeroid genera (G) or genera and species (s) identified in the Ptychagnostus atavus Zone of the Henson Gletscher and Kap Stanton formations (hyphen indicates absence of a genus). Abbreviations of geographic regions are AN, northern Appalachia (western Newfoundland and Quebec); AM, middle Appalachia (New York and Pennsylvania); GB, Great Basin (Utah and Nevada); AL, east-central Alaska; CR, southern Canadian Rocky Mountains; CM, maritime Canada except for western Newfoundland; SW, Sweden; EN, England south of the Caledonian suture; SP, Siberian platform; and AU, Australia. 
Table 4. Distributions of polymeroid genera in the Lejopyge laevigata Zone of the Kap Stanton Formation

\begin{tabular}{lcccccccccc}
\hline TAXA & AM & GB & SW & NO & EN & CM & BO & BI & SP & AU \\
\hline Anomocarina excavata & - & - & s & s & - & - & - & s & s & - \\
Centropleura angelini & G & G & s & - & G & G & G & G & G & G \\
Centropleura loveni & G & G & S & - & G & G & G & G & s & G \\
Elyx trapezoidalis & G & - & G & G & - & G & - & - & G & - \\
Solenopleura bucculenta & G? & - & s & G & G & - & - & - & G & - \\
\hline
\end{tabular}

Observed geographic distributions of polymeroid genera (G) or genera and species (s) identified in the Lejopyge laevigata Zone of the Kap Stanton Formation (hyphen indicates absence of a genus). Abbreviations of geographic regions are AM, middle Appalachia (New York and Vermont); GB, Great Basin (Nevada); SW, Sweden; NO, Norway; EN, England south of the Caledonian suture; CM, maritime Canada except for western Newfoundland; BO, Bohemia; BI, Bennett Island; SP, Siberian platform; and AU, Australia.

This, together with the numerous pelagic agnostoids in GGU 298970 (Robison, 1994), suggests that trilobites in this collection had unrestricted access to the open ocean.

Polymeroids in new collections (Babcock, 1994) representing the Ptychagnostus atavus Zone are of mixed Laurentian and Baltic aspect (Table 3), and those in the Lejopyge laevigata Zone are entirely of Baltic aspect (Table 4). Patterns in the palaeogeographic distributions of polymeroids occurring in these two zones in North Greenland were explored using multivariate methods. Results, summarised in the following section, reveal a strong distinction between major faunal associations (biofacies) and some subtle but important associations.

\section{Multivariate analyses of trilobite collections}

Multivariate methods were used to explore patterns of faunal association among polymeroid trilobites from selected localities in North Greenland, North America, Scandinavia, and Great Britain. Faunas analysed are from the Ptychagnostus atavus and Lejopyge laevigata zones.

Binary (presence-absence) data were analysed using cluster analysis (CA) and multidimensional scaling (MDS). Analyses were performed using version 3 of the SYSTAT statistical package (SYSTAT, Inc.) on an Apple Macintosh II computer. Cluster analysis was used to separate data sets into discrete groups (see Hazel, 1970, 1977). In Q-mode analyses, objects (collections) were related to each other on the basis of their attributes (genera). In R-mode analyses, attributes (genera) were related to each other on the basis of the objects (collections) in which they occur. Clustering was performed on Euclidean distance coefficients using average linkage and unweighted pair group arithmetic means. Euclidean distance has the advantage of producing a distribution that closely approximates to the binomial probability distribution with data that are not sparse (C. G. Maples, personal communication, 1990). Therefore, values of Euclidean coefficients can be tested for statistical significance by using binomial probabilities (see Archer \& Maples, 1987; Maples \& Archer, 1988). Confidence intervals established for clusters on data from the L. laevigata and $P$. atavus zones are listed in Table 5.

To test further the reliability of clusters, MDS was used in a manner analogous to $\mathrm{R}$ mode. The rationale for using it is that CA can distort between-group relationships, although relationships within compact groups are likely to be accurate (Kruskal, 1964a, 1964b; Hazel, 1977). MDS distributes distortion evenly between large and small distances (Hazel, 1977). Lastly, fidelity and constancy indices (Hazel, 1970, 1977; Hood \& Robison, 1988) were calculated for all genera in principal clusters as measures of how well they characterise a particular cluster. A fidelity index measures the extent to which a taxon is confined to samples of a cluster. Fidelity (F) is defined by

$$
\mathrm{F}_{\mathrm{ji}}=\mathrm{N}_{\mathrm{i}} / \Sigma \mathrm{N}_{\mathrm{i}} \star 10
$$

where $\mathrm{N}_{\mathrm{i}}$ is the number of collections in each cluster in

\section{Table 5. Confidence intervals for clusters of} trilobite presence-absence data

\begin{tabular}{lcccc}
\hline ZONE & $\mathrm{N}$ & $P<0.10$ & $P<0.05$ & $P<0.01$ \\
\hline Lejopyge laevigata & 27 & 0.75 & 0.81 & 0.89 \\
Ptychagnostus atavus & 21 & 0.77 & 0.83 & 0.90
\end{tabular}

Confidence intervals for clusters of trilobite presence-absence data produced in Q-mode and R-mode, derived from a comparison of Euclidean distance coefficients to a binomial distribution (data provided by C. G. Maples). Samples on which cluster analysis was performed are from the Lejopyge laevigata and Ptychagnostus atavus zones. Coefficients greater than the listed values are considered to be statistically dissimilar. $\mathrm{N}$ indicates the number of columns in the data matrices. 
which the species is present, and $\Sigma N_{i}$ is the total number of collections in which the species is present. A constancy index measures the extent to which a taxon is present in samples of a cluster compared to all possible occurrences. Constancy (C) is defined by

$$
\mathrm{C}_{\mathrm{ji}}=\mathrm{N}_{\mathrm{i}} / \mathrm{T}_{\mathrm{i}} \star 10
$$

where $T_{i}$ is the total number of samples in a cluster. Both indices are rounded to the nearest whole number. Genera having both high fidelity and high constancy indices best define a cluster (Hazel, 1970).

Data on genera from 9 localities in the L. laevigata Zone and 10 localities in the $P$. atavus Zone were analysed. Collections chosen for analysis are either new (GGU 298969, 301313, and 319790) or from the published literature. Data compiled from published sources are mostly based on well-described collections but some identifications by Kindle (1982) are considered to be preliminary. For some taxa, nomenclatural revisions have been made to bring names into conformity with current taxonomic concepts. Except for GGU collections, collections were agglomerative and commonly included taxa pooled from two or more geographically close localities. Binary data, rather than frequency data, were chosen because taphonomic factors, including effects of preservation, diagenesis, and collecting, can render comparisons between frequency data suspect (Archer \& Maples, 1987). Samples used are not of uniform size, and are not necessarily from the same ecological context (see Kaesler, 1966). Furthermore, the numerical abundance of preserved and identified taxa probably does not faithfully represent the original faunal composition (see Staff et al., 1986). Trilobite data from other parts of the world were not included in the analysis partly because of differences in some generic concepts as applied outside of North America and western Europe. Also, the tendency of many shelf-dwelling Cambrian polymeroid genera to be endemic to a region or continent would produce data sets containing few presences and a large number of absences. Such sparse data will tend to skew calculations to emphasise differences between localities. Furthermore, they will tend to truncate zones of statistical significance (Maples $\&$ Archer, 1988).

Complete and reduced data matrices were analysed. The complete data matrix for samples from the L. laevigata Zone consisted of 75 genera from nine localities (collections). For the $P$. atavus Zone it consisted of 37 genera from 10 localities. In the reduced data matrices, genera present in only one collection were eliminated from analyses. Such taxa may be important constituents of individual collections, but they yielded little comparative information and tended to increase distance coeffi- cients between collections. The smaller matrices contained 27 genera from the L. laevigata Zone and 21 genera from the $P$. atavus Zone. Both the complete and reduced matrices produced similar patterns of clusters. Different values of coefficients evidently resulted from collections that contained large numbers of genera not present in other collections. To illustrate better the similarities among collections, only results based on the smaller data matrices are discussed.

Analysed collections from the L. laevigata Zone include two from North Greenland (GGU 301313, herein; and Holm Dal Formation, Robison, 1988), four from Scandinavia (Scania and Västergötland in Sweden, Bornholm in Denmark, and Norway; Westergård, 1946, 1953), one from southern Great Britain (Thomas et al., 1984), one from eastern Canada (Cow Head Group of Quebec, Kindle, 1982), and one from western North America (House Range, Utah; Robison, 1964, personal communication, 1989; Beebe, 1989).

Q-mode CA produced two principal clusters containing similar genera (Fig. 3, A, B). The average distance coefficient between clusters $A$ and $B$ is 0.82 . The null hypothesis that there is no difference between these clusters is rejected at the 0.05 level (see Table 5). Cluster A includes GGU 301313 and collections from localities in Scandinavia and Great Britain south of the Caledonian suture. Cluster B includes collections from the Holm Dal Formation of North Greenland, the House Range of Utah, and the Cow Head boulders of western Newfoundland. The principal clusters correspond to localities that have polymeroid genera entirely of Baltic and Laurentian aspect, respectively. The lack of taxonomic overlap between collections may be partially a function of the collections chosen for study, but in large measure it seems to be indicative of a fundamental difference between trilobite biofacies. Examination of available literature shows that less than five percent of all polymeroids recorded from shelf lithofacies in the $L$. laevigata Zone of Laurentia are also present in coeval rocks of Baltica and the peri-Gondwanan terranes.

R-mode cluster analysis produced two primary clusters (Fig. 3, I, II) that show which groups of genera are responsible for the Q-mode clusters. The average distance coefficient between clusters I and II is 0.82 . The null hypothesis that there is no difference between clusters is rejected at the 0.05 level (see Table 5). Cluster I contains 16 genera that are either geographically widespread or restricted to sites in North Greenland, Scandinavia, or Great Britain. Genera that previously have been observed only in Baltica include Acrocephalites, Dolichometopus, and Gronwallia. Agraulos, Bailiaspis, and Paradoxides have wider distributions but are best known from regions that were in high palaeolatitudes, including 
Fig. 3. Cluster analysis of data on polymeroid collections from the Lejopyge laevigata Zone of North Greenland and selected localities in North America, Scandinavia, and Great Britain. Data are plotted in order formed by Q-mode clustering of collections and R-mode clustering of genera. Primary clusters are labelled with Roman numerals and uppercase letters. Cluster A contains genera of Baltic aspect, and cluster $B$ contains genera of Laurentian aspect.

\section{R-mode clusters}

\section{Q-mode clusters}

\section{Euclidean distance}
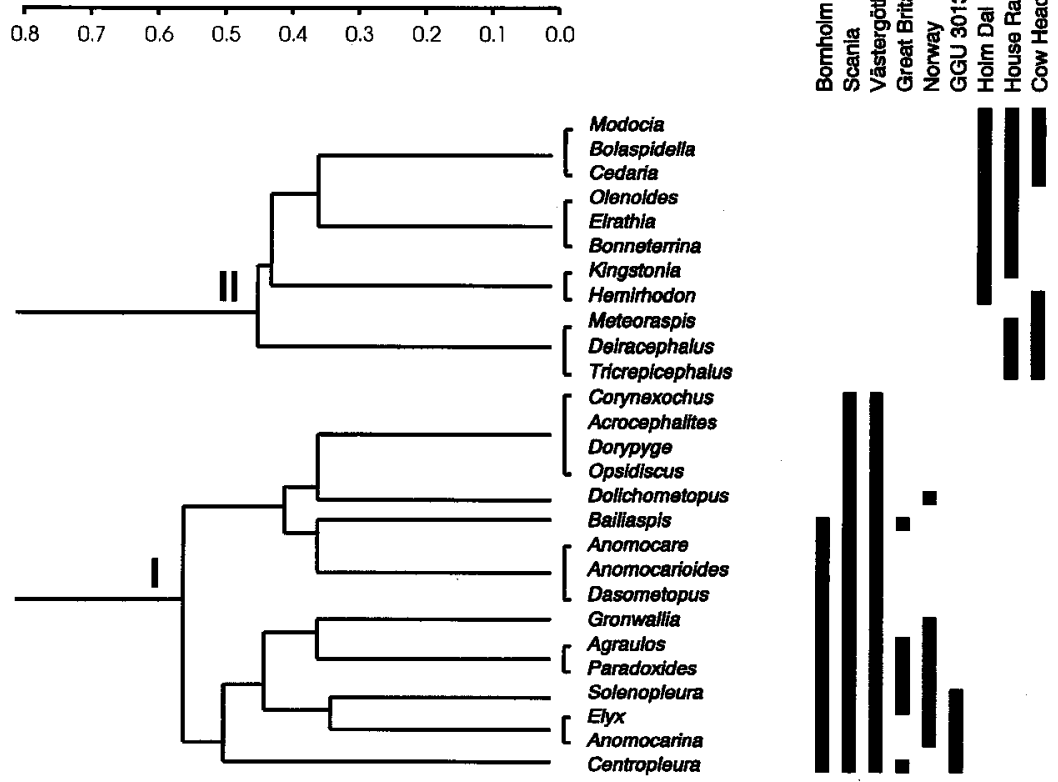

Baltica, Gondwana, and peri-Gondwanan terranes. Anomocarina, Anomocarioides, and Dasometopus are known from sites in Baltica and Siberia. Dasometopus and Anomocarina are reported by Babcock (1994) from North Greenland. Elyx has now been observed in Baltica, Siberia, Acadia, and North Greenland. From published records, Centropleura, Corynexochus, Opsidiscus, and Solenopleura all have relatively wide distributions, although not necessarily during the L. laevigata Biochron.

Cluster II contains eleven genera which are restricted to Laurentia except Olenoides and Modocia. Olenoides is diverse in Laurentia but was also present in shelf seas of Siberia, Kazakhstania, China, and the Precordillera terrane of Argentina. It, like some other genera assigned to the Dorypygidae (Poulsen in Harrington et al., 1959: O217-0219), seems to have been widely distributed in
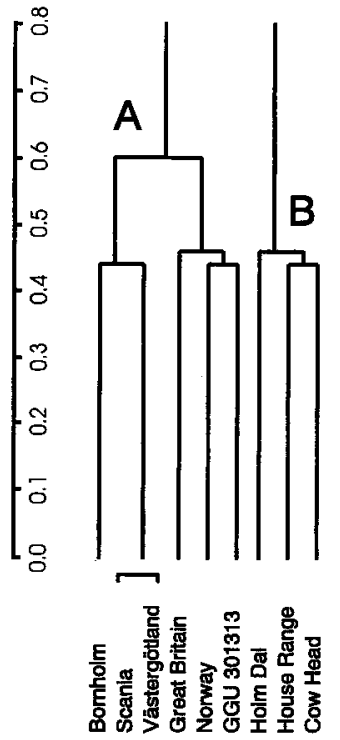

low palaeolatitudes. Modocia is a common and diverse genus in Laurentia, and the only verified occurrence other than Laurentia is a single specimen from England (Rushton, 1978).

Results using MDS (Fig. 4) are in close agreement with results of the CA. Genera that formed clusters in R-mode analysis form discrete, rather compact groups in two-dimensional MDS. The first dimension represents a contrast between the 16 genera of Baltic aspect and the 11 genera of Laurentian aspect. The second dimension primarily represents a contrast between more widespread genera and less widespread ones.

Fidelity and constancy indices for clusters (Fig. 3) are listed in Table 6. Cluster I contains 16 genera that define cluster A and have been collected from localities in Scandinavia, Great Britain, or Peary Land, North Greenland 


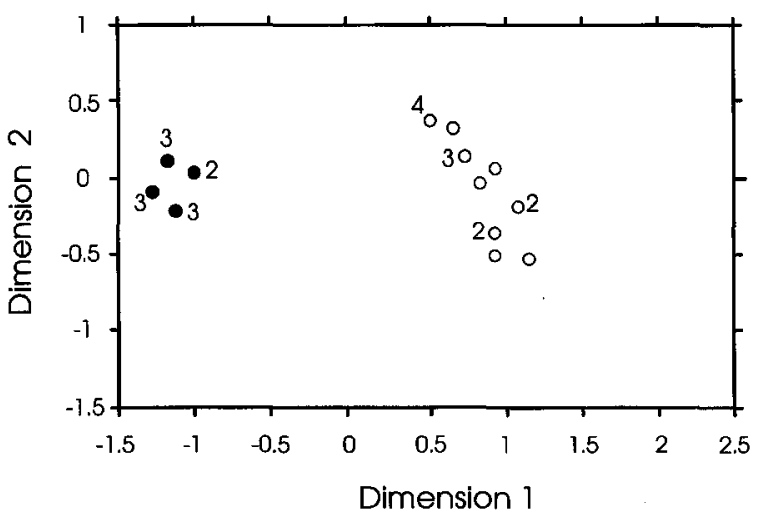

Fig. 4. Scattergram of coordinates of genera analysed by multidimensional scaling. Taxa analysed are from the Lejopyge laevigata Zone. Open circles correspond to polymeroid genera of Baltic aspect as defined in Q-mode cluster analysis, and closed circles correspond to genera of Laurentian aspect. A numeral next to a circle indicates the number of genera that are stacked vertically at that point.

(GGU 301313). All have high fidelity indices. Genera that also have high constancy indices are Agraulos, Anomocarina, Bailiaspis, Centropleura, Elyx, Gronwallia, Paradoxides, and Solenopleura. Some genera appear to have been largely restricted to Baltica and England but, as indicated above, this is an artifact of the localities that were chosen for analysis. Cluster II includes genera that define cluster B and that are most common in open-shelf lithofacies of North America. All have high fidelity and constancy indices. Except for Olenoides and Modocia, all are restricted to Laurentia. Extra-Laurentian samples containing these genera, however, were not included in the analysis.

Trilobite samples from the L. laevigata Zone of the Kap Stanton Formation are interpreted to represent autochthonous associations of trilobites in deep, outermost shelf or possibly upper slope lithofacies. Specimens are commonly articulated and fragile fossils preserved parallel to bedding in dark, organic-rich lime mudstone. Disarticulated sclerites are also common, but are generally unbroken. Some specimens represent undisturbed moulted exoskeletons. Specimens range from small meraspides to large holaspides. Little post-mortem or postmoulting transportation of sclerites is indicated. Furthermore, the presence of undisturbed laminae indicates little or no faunal mixing by bioturbation. All four genera and four of five species present in these collections (Table 4) are also present in coeval rocks of Scandinavia. Some genera or species are found in open-shelf lithofacies of southern Great Britain, Siberia, Kazakhstan, Australia, or China. None of the genera is present in coeval rocks of the Holm Dal Formation (see Robison, 1988). This is remarkable in view of the fact that section 3 , where trilobites of Baltic aspect were found, is only about $40 \mathrm{~km}$ from the type section of the Holm Dal Formation in Peary Land (Fig. 1). The Holm Dal Formation contains trilobites primarily of Laurentian aspect (see Robison, 1988). Major tectonic dislocation has not been observed in this region (Fletcher et al., 1988; Higgins et al., 1991). Rocks of the Holm Dal Formation represent an inferred low energy, open-shelf environment (Ineson, 1988); water depths were probably significantly less than those in which the sediments of the lower Kap Stanton Formation, as seen along J. P. Koch Fjord, were deposited.

Collections analysed from the $P$. atavus Zone include two from North Greenland (GGU 298969 and 319790; Babcock, 1994), one from western North America (House Range, Utah; Robison, 1964 and unpublished data), two from eastern Canada (Cow Head Group, Quebec, Kindle, 1982; and south-eastern Newfoundland,

Table 6. Fidelity and constancy indices for polymeroids from the Lejopyge laevigata Zone

\begin{tabular}{|c|c|c|c|c|c|c|}
\hline & \multicolumn{3}{|c|}{ CLUSTER A } & \multicolumn{3}{|c|}{ CLUSTER B } \\
\hline & $\mathbf{F}$ & $\mathrm{C}$ & $\mathbf{N}$ & $\mathrm{F}$ & $\mathrm{C}$ & $\mathrm{N}$ \\
\hline Modocia & - & - & - & 10 & 10 & 3 \\
\hline Bolaspidella & - & - & - & 10 & 10 & 3 \\
\hline Cedaria & - & - & - & 10 & 10 & 3 \\
\hline Olenoides & - & - & - & 10 & 7 & 2 \\
\hline Elrathia & - & - & - & 10 & 7 & 2 \\
\hline Bonneterrina & - & - & - & 10 & 7 & 2 \\
\hline Kingstonia & - & - & - & 10 & 7 & 2 \\
\hline Hemirhodon & - & - & - & 10 & 7 & 2 \\
\hline Meteoraspis & - & - & - & 10 & 7 & 2 \\
\hline Deiracephalus & - & - & - & 10 & 7 & 2 \\
\hline Tricrepicephalus & - & - & - & 10 & 7 & 2 \\
\hline Corynexochus & 10 & 3 & 2 & - & - & - \\
\hline Acrocephalites & 10 & 3 & 2 & - & - & - \\
\hline Dorypyge & 10 & 3 & 2 & - & - & - \\
\hline Opsidiscus & 10 & 3 & 2 & - & - & - \\
\hline Dolichometopus & 10 & 5 & 3 & - & - & - \\
\hline Bailiaspis & 10 & 7 & 4 & - & - & - \\
\hline Anomocare & 10 & 5 & 3 & - & - & - \\
\hline Anomocarioides & 10 & 5 & 3 & - & - & - \\
\hline Dasometopus & 10 & 5 & 3 & - & - & - \\
\hline Gronwallia & 10 & 7 & 4 & - & - & - \\
\hline Agraulos & 10 & 8 & 5 & - & - & - \\
\hline Paradoxides & 10 & 8 & 5 & - & - & - \\
\hline Solenopleura & 10 & 10 & 6 & - & - & - \\
\hline Elyx & 10 & 8 & 5 & - & - & - \\
\hline Anomocarina & 10 & 8 & 5 & - & - & - \\
\hline Centropleura & 10 & 8 & 5 & - & - & - \\
\hline
\end{tabular}

Fidelity (F) and constancy (C) indices for polymeroids in two Q-mode clusters shown in Fig. 3 from the Lejopyge laevigata Zone. The number of collections containing a genus is listed under N. A hyphen indicates the absence of a genus from a cluster. 
Hutchinson, 1962), three from Scandinavia (Norway, Västergötland, and Bornholm; Westergård, 1946, 1953), and one from southern Great Britain (Thomas et al., 1984). The GGU collections include specimens in both mudstone and packstone. Genera preserved in both lithologies were grouped together in this analysis because all that are present in mudstone are also present in packstone.

CA in Q mode produced two primary clusters (Fig. 5, A, B) that show major faunal differences between collections containing polymeroids of Laurentian and Baltic aspect. The Euclidean distance coefficient between clusters $A$ and $B$ is 0.76 , which is considered to be of borderline statistical significance at the 0.1 level (see Table 5). Cluster A contains collections from Great Britain, south-eastern Newfoundland, Scandinavia (Västergötland, Bornholm, Scania, and Norway), and North Greenland (GGU 298969 and 319790). Cluster B con- tains collections from the House Range, Utah, and the Cow Head Group, western Newfoundland.

GGU collections 298969 and 319790 from North Greenland and collections from boulders of the Cow Head Group of Newfoundland all consist of mixed assemblages of polymeroids having Laurentian and Baltic aspect. All polymeroids in the GGU collections preserved in mudstone are of Baltic aspect and probably represent trilobites indigenous to the deep, outermost shelf lithofacies. Most polymeroids preserved in packstone are also of Baltic aspect. One of 5 genera ( 20 percent) in GGU 298969 and 2 of 6 genera (33 percent) in GGU 319790, however, are of Laurentian aspect. Most polymeroids from the Cow Head collections are of Laurentian aspect but 4 of 10 genera ( 40 percent) are of Baltic aspect. A few trilobites of Laurentian or Baltic aspect may have coexisted in some places, but the differences between taxa preserved in mudstone and packstone in North Greenland

\section{R-mode clusters}

Fig. 5. Cluster analysis of data on polymeroid collections from the Ptychagnostus atavus Zone of North Greenland and selected localities in North America, Scandinavia, and Great Britain. Data are plotted in order formed by Qmode clustering of collections and R-mode clustering of genera. Primary clusters are labelled with Roman numerals and uppercase letters. Cluster A contains genera of Baltic aspect (except Olenoides, Bathyuriscus, and Syspacephalus), and cluster B contains genera of Laurentian aspect.
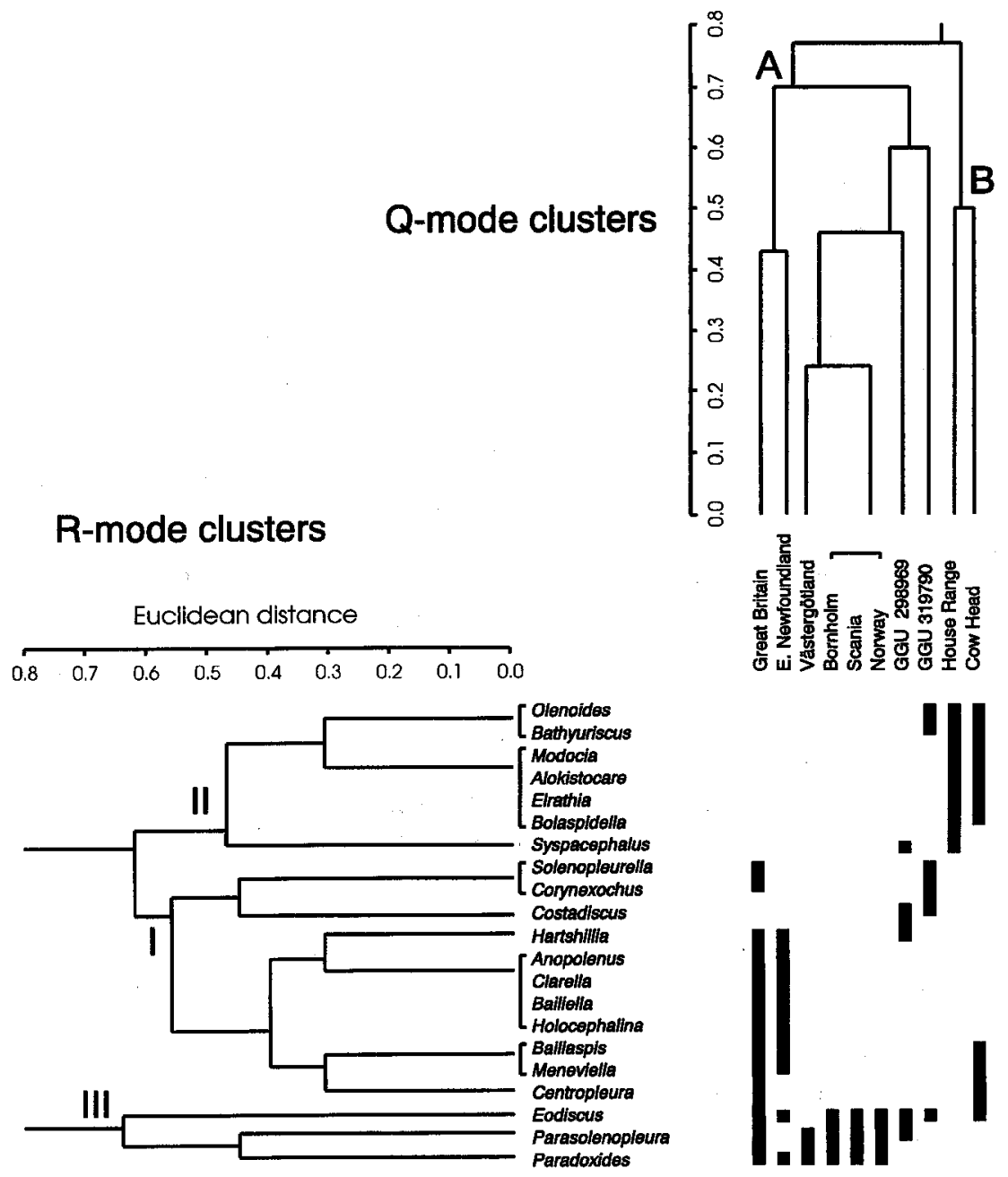


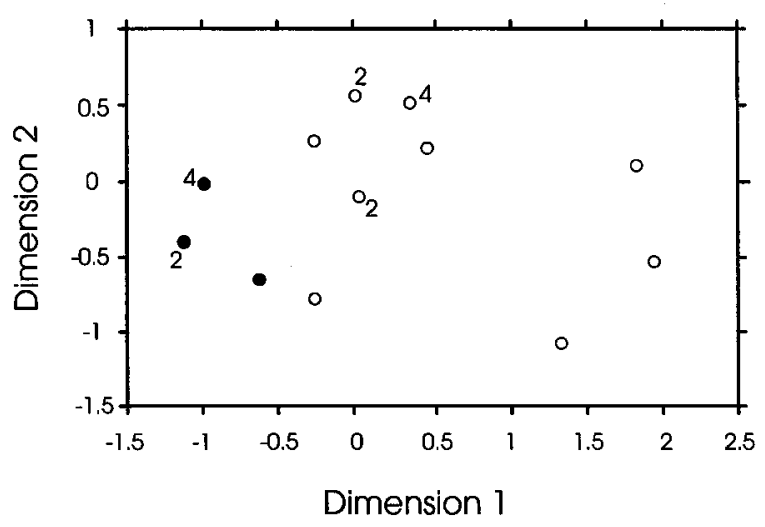

Fig. 6. Scattergram of coordinates of genera analysed by multidimensional scaling. Taxa analysed are from the Ptychagnostus atavus Zone. Open circles correspond to polymeroid genera of Baltic aspect as defined in Q-mode cluster analysis, and closed circles correspond to genera of Laurentian aspect. A numeral next to a circle indicates the number of genera that are stacked vertically at that point.

suggest that biofacies of polymeroids were strongly differentiated.

Stratigraphic and sedimentologic evidence suggest that trilobites in GGU collections 298969 and 319790 and collections from the Cow Head Group have been mixed by sedimentary processes. All of these collections contain disarticulated and fragmented trilobite sclerites and occur in deeper-water successions that accumulated basinward of steep-rimmed, shallow-water carbonate platforms. The specimens from North Greenland that are preserved in packstone are crudely size-sorted, and are interpreted to have been redeposited by sediment gravity flows (see Ineson, 1980 and discussion in Ineson et al., 1994). The Cow Head material was collected from limestone breccia that was inferred to have been deposited by gravity flow (Hubert et al., 1977; Hiscott \& James, 1985; James \& Stevens, 1986). Boulders in the Cow Head Group represent several depositional lithofacies (Kindle, 1982; James \& Stevens, 1986).

R-mode CA produced three primary clusters (Fig. 5, I-III). Cluster I contains all of the genera of Baltic aspect except Eodiscus, Parasolenopleura, and Paradoxides, which form cluster III. Genera in clusters I and III are responsible for cluster A produced in Q mode. Cluster II contains seven genera characteristic of open-shelf sites in Laurentia. These taxa are responsible for cluster B produced in Q mode. The average Euclidean distance coefficient between clusters I and II is 0.63 . The null hypothesis that there is no difference between clusters I and II cannot be rejected $(P>0.1$; see Table 5$)$. The rather low distance coefficient is probably due mostly to the presence of three mixed collections (GGU 298969, GGU
319790, and Cow Head Group) in the analysis. The distance coefficient between clusters I + II and III is 0.82 , which is considered to be of borderline statistical significance at the 0.1 level (see Table 5). Cluster III contains three genera that were evidently widespread. The cluster has a high level of dissimilarity from the other clusters probably because the contained genera are widely distributed among localities that contain polymeroids of Baltic aspect.

Results of MDS (Fig. 6) illustrate the relatively lower distance coefficients between clusters containing polymeroids of mostly Baltic aspect (Fig. 5, A) and Laurentian aspect (Fig. 5, B), compared to samples analysed from the L. laevigata Zone. Genera that comprise clusters A and B form loose clusters. Most of the taxa in cluster B have coordinates near those in cluster A. Eodiscus, Paradoxides, and Parasolenopleura have coordinates that are most distant from taxa in cluster A. The first axis has been fitted primarily to the contrast between polymeroids of Laurentian and Baltic aspect. The second axis is fitted primarily to the contrast between more widespread and less widespread genera.

Fidelity and constancy indices for polymeroids from

Table 7. Fidelity and constancy indices for polymeroids from the Ptychagnostus atavus Zone

\begin{tabular}{|c|c|c|c|c|c|c|}
\hline & \multicolumn{3}{|c|}{ CLUSTER A } & \multicolumn{3}{|c|}{ CLUSTER B } \\
\hline & $\mathbf{F}$ & $\mathrm{C}$ & $\mathrm{N}$ & $\mathrm{F}$ & $\mathrm{C}$ & $\mathbf{N}$ \\
\hline Olenoides & - & - & - & 7 & 10 & 3 \\
\hline Bathyuriscus & - & - & - & 7 & 10 & 3 \\
\hline Modocia & - & - & - & 10 & 10 & 2 \\
\hline Alokistocare & - & - & - & 10 & 10 & 2 \\
\hline Elrathia & - & - & - & 10 & 10 & 2 \\
\hline Bolaspidella & - & - & - & 10 & 10 & 2 \\
\hline Syspacephalus & - & - & - & 5 & 5 & 2 \\
\hline Solenopleurella & 10 & 3 & 2 & - & - & - \\
\hline Corynexochus & 10 & 3 & 2 & - & - & - \\
\hline Costadiscus & 10 & 3 & 2 & - & - & - \\
\hline Hartshillia & 10 & 4 & 3 & - & - & - \\
\hline Anopolenus & 10 & 3 & 2 & - & - & - \\
\hline Clarella & 10 & 3 & 2 & - & - & - \\
\hline Bailiella & 10 & 3 & 2 & - & - & - \\
\hline Holocephalina & 10 & 3 & 2 & - & - & - \\
\hline Bailiaspis & 7 & 3 & 3 & - & - & - \\
\hline Meneviella & 7 & 3 & 3 & - & - & - \\
\hline Centropleura & 5 & 1 & 2 & - & - & - \\
\hline Eodiscus & 9 & 9 & 8 & - & - & - \\
\hline Parasolenopleura & 10 & 8 & 6 & - & - & - \\
\hline Paradoxides & 10 & 8 & 6 & - & - & - \\
\hline
\end{tabular}

Fidelity (F) and constancy (C) indices for polymeroids in two Q-mode clusters shown in Fig. 5 from the Ptychagnostus atavus Zone. The number of collections containing a genus is listed under $\mathrm{N}$. A hyphen indicates the absence of a genus from a cluster. 
the $P$. atavus Zone are listed in Table 7. Except for Centropleura, all 14 genera that produced cluster A have high fidelity indices. Those that also have high constancy indices are Eodiscus, Paradoxides, and Parasolenopleura. All genera in cluster B except Syspacephalus have high fidelity and constancy values. Syspacephalus is restricted to Laurentia, but disarticulated sclerites have been found in one mixed assemblage, GGU 298969, in which most polymeroids are of Baltic aspect.

In summary, collections from packstone beds of the $P$. atavus Zone of North Greenland (e.g., GGU 298969 and 319790) contain polymeroids of both Laurentian and Baltic aspects. Most examined specimens are disarticulated and fragmented. Polymeroids in the intervening mudstones are entirely of Baltic aspect, and tend to be found articulated. Trilobites in mudstone are interpreted to have been indigenous to the deep outermost shelf. Those in packstone, however, have probably been mixed by sediment gravity-flow processes introducing skeletal material typical of outer-shelf environments into the deeper-water setting.

\section{Environmental relationships of trilobites}

Middle Cambrian strata of the L. laevigata and $P$. atavus zones of North Greenland include biofacies dominated by polymeroids having either Laurentian or Baltic aspect. Trilobites of Baltic aspect were evidently indigenous to the deep outermost shelf or upper basin slope, whereas those of Laurentian aspect inhabited open-shelf lithofacies. Resedimentation of trilobite sclerites has resulted in the mixing of trilobites of different aspects in some beds of the $P$. atavus Zone (Fig. 7).

In recent years, faunal differences in Cambrian rocks have been commonly attributed to environmental gradients in which temperature played a major role (Cook \& Taylor, 1975, 1977; Taylor, 1976, 1977; Taylor \& Cook 1976; Taylor \& Forester, 1979; Theokritoff, 1979; Conway Morris \& Rushton, 1988; Shergold, 1988; Babcock \& Robison, 1989; Robison \& Babcock, 1990). Stratigraphic and biogeographic evidence has been presented to show that some oceans were thermally stratified during the Early Cambrian (Theokritoff, 1979) and the Late Cambrian (e.g., Taylor \& Forester, 1979), just as they are during the Holocene (e.g., Benson, 1975, 1988). The results presented in this paper suggest that ocean waters

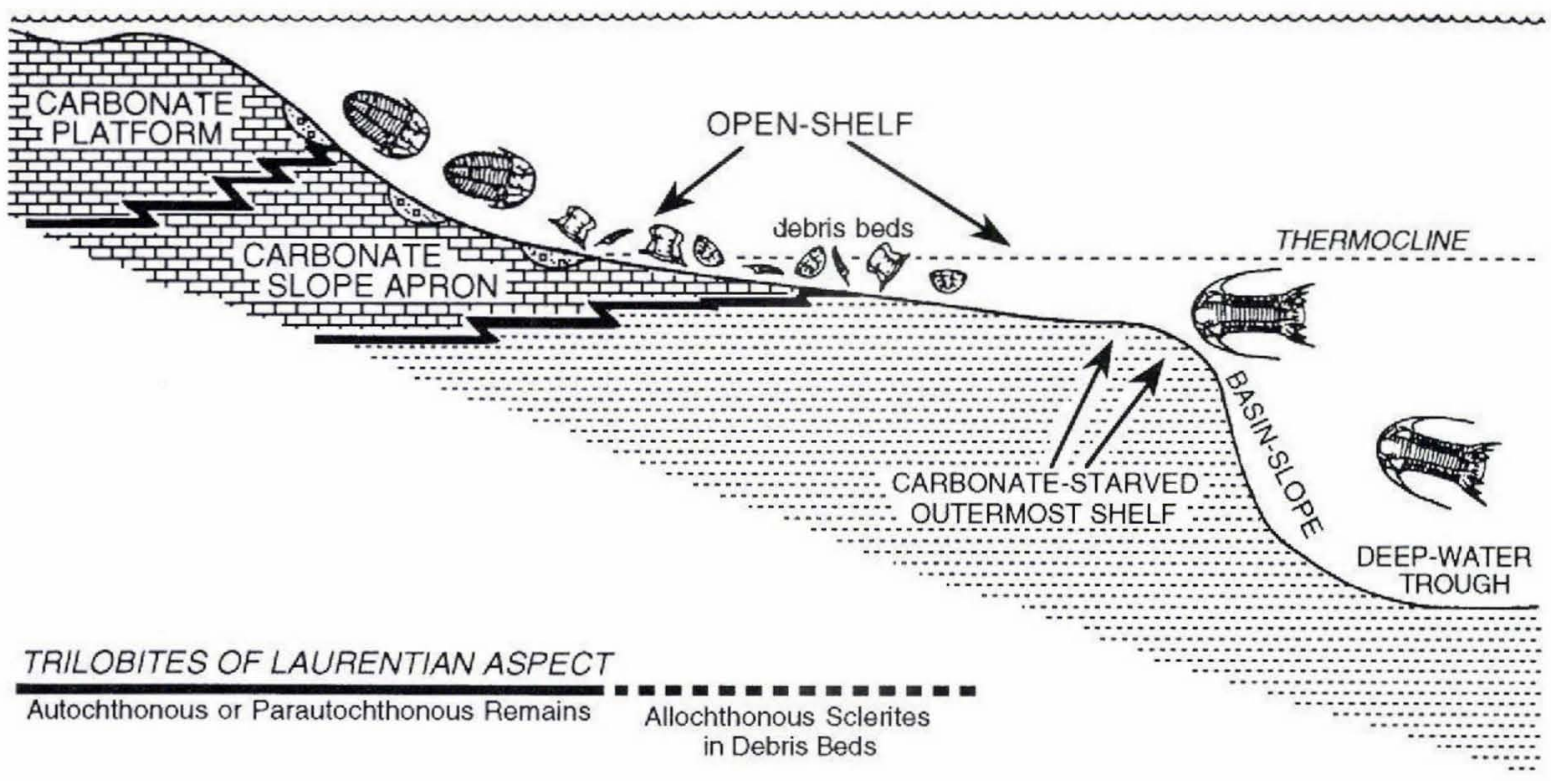

TRILOBITES OF BALTIC ASPECT

Autochthonous or Parautochthonous Remains

Fig. 7. Model of the Innuitian margin of Laurentia off present-day North Greenland during the Middle Cambrian illustrating the relationships of physiography, sedimentation patterns, and trilobite biofacies. Polymeroid trilobites of Baltic aspect (represented by Centropleura, right) are inferred to have lived below the permanent thermocline. Fossils of Baltic trilobites are preserved in lime mudstone and are commonly articulated. Polymeroids of Laurentian aspect (represented by Bathyuriscus, left) are inferred to have lived in warm shallower water above the thermocline but their disarticulated remains (represented by isolated sclerites of Bathyuriscus) were dispersed basinward by gravity displacement of sediment and redeposited in debris beds. 
surrounding Laurentia were also thermally stratified during the Middle Cambrian (Fig. 7). Other postulated explanations for biogeographic barriers, including a deepwater basin (see Wilson, 1966; Cowie, 1971) and a land barrier (Ulrich \& Schuchert, 1902), were reviewed by Theokritoff (1979). Theokritoff rejected the idea that a deep-water basin was alone sufficient to act as a biogeographic barrier on both uniformitarian arguments and evidence about the distribution of some Early Cambrian trilobites. The notion of a land barrier was rejected on the basis of biogeographic and stratigraphic evidence.

The terms thermosphere and psychrosphere (Bruun, 1957) describe the divisions of the world oceans that are respectively above and below the permanent thermocline. In low and intermediate latitudes, warmer, less dense waters of the thermosphere, which are characterised by temperatures higher than $10^{\circ} \mathrm{C}$, float above cooler, more dense waters of the psychrosphere, which are characterised by temperatures lower than $10^{\circ} \mathrm{C}$ (Bruun, 1957; Benson, 1975). In present-day, high-latitude shelf areas, the thermosphere is not present.

Based on an analysis of modern isopod biofacies, Taylor \& Forester (1979) found that faunas indigenous to warm shelves in low latitudes show strong similarities to other warm-water faunas and strong dissimilarities to faunas in cool marine waters. Those from cool waters show a high degree of similarity whether they are in high latitudes or in low latitudes below the permanent thermocline. It is likely that thermal stratification of water masses during parts of the early Palaeozoic similarly affected the biogeographic distributions of trilobites (see Taylor \& Forester, 1979). The mostly endemic shelf faunas of Laurentia are inferred to have been adapted to warm water, whereas faunas described from shelf areas of Baltica and southern Gondwana or from peri-Gondwanan terranes located in south-polar regions are inferred to have been adapted to cool water.

Taylor \& Forester (1979) listed three criteria that they considered to be necessary to demonstrate the presence of a two-layered thermally stratified Palaeozoic ocean. They are (1) evidence of deep-water environments, (2) strong biofacies differences between indigenous faunas of deepwater environments and those of adjacent warm shelves, and (3) widely distributed deep-water faunas that show greatest taxonomic resemblance to faunas in other deepwater environments and shallow-water environments of high latitudes.

Rocks and faunas of the L. laevigata and P. atavus zones of North Greenland meet Taylor \& Forester's criteria. First, deep-water shelf environments, basinward of the carbonate platform are represented by the Henson Gletscher and Kap Stanton formations. Rocks from those units are interpreted (Ineson et al., 1994) to represent open-shelf to deep, outermost shelf (or possibly basinslope) environments along the Innuitian margin of Laurentia.

Second, indigenous deeper-water polymeroid faunas of North Greenland show strong dissimilarities with coeval faunas from the adjacent warm-water Laurentian shelf. Polymeroid faunas of the $L$. laevigata Zone that were indigenous to putative deep, outermost shelf environments do not share any genera or species with a fauna reported from the coeval Holm Dal Formation (Robison, 1988), which was deposited in an inferred low energy, open-shelf setting (Ineson, 1988). Trilobites described from the type section of the Holm Dal Formation were collected approximately $40 \mathrm{~km}$ south of locality 3 (Fig. 1), indicating that faunal changes between the shelf and slope were abrupt.

Shallower water faunas from the $P$. atavus Zone of North Greenland were not available for comparison. Nevertheless, comparison of trilobites in mudstone and packstone from GGU collections 298969, 319789, and 319790 indicate a strong faunal dissimilarity between putative open-shelf-dwelling and deep, outermost shelfdwelling polymeroids. Some polymeroids found as resedimented particles in GGU collections are interpreted to have been derived from open-shelf settings where polymeroids of Laurentian aspect predominated. Two species, Olenoides cf. O. convexus and Solenopleurella transversa, have been previously described from open-shelf sites elsewhere in Laurentia. Except for the eodiscid Costadiscus, which is known only from North Greenland, polymeroids in undisturbed mudstone are exclusively of Baltic aspect.

Finally, polymeroids indigenous to putative deep, outermost shelf or upper slope environments of the L. laevigata and $P$. atavus zones in North Greenland are taxonomically most similar to faunas from shallow-shelf environments of cool, high-latitude areas of Baltica, Acadia, Armorica, and England. Some taxa, including Centropleura, Eodiscus, and solenopleurids, are also known from deep-water Laurentian sites in north-western Vermont (Howell, 1937; Shaw, 1966), south-eastern New York (Rasetti, 1967) and central Nevada (Stewart \& Palmer, 1967; Palmer \& Stewart, 1968; Babcock, 1990). Indigenous deep-water polymeroids of the Henson Gletscher and Kap Stanton formations evidently did not also inhabit shallower water environments of the Laurentian shelf. Where trilobites of mixed Laurentian and Baltic aspect have been found in the same beds, evidence suggests that they were brought together by taphonomic processes.

Polymeroids of the $P$. atavus Zone in Nyeboe Land support stratigraphic and structural evidence (Fletcher $e t$ al., 1988; Higgins et al., 1991; Surlyk, 1991) that these 
rocks are in situ and were not accreted by plate collision. Minimal fragmentation and lack of size sorting suggest that specimens preserved in mudstone probably are autochthonous or parautochthonous to environments at continental margins, including deep, outermost shelf and perhaps slope areas. Specimens in packstone, which are more fragmented and size sorted, are interpreted to have been redeposited. Many were probably carried basinward from proximal shelf sites by gravity flows. Analogous deposits containing resedimented trilobites that were near the Laurentian continental margin have been described from the Upper Cambrian of central Nevada (Cook \& Taylor, 1975, 1977; Taylor, 1976; Taylor \& Cook, 1976). There, redeposited warm-water trilobites of Laurentian aspect are interbedded with indigenous trilobites having an Asian aspect. Other possible continental slope deposits that contain resedimented trilobites of mixed provincial affinities (Taylor \& Forester, 1979) include some in the Taconic sequence of New York (Bird \& Theokritoff, 1968; Bird \& Rasetti, 1968), the Cow Head Group of western Newfoundland (Babcock, 1991; see Kindle, 1982), and the Collier Shale of Arkansas (Hart et al., 1987; Hohensee \& Stitt, 1989).

\section{Geological implications}

During the Middle Cambrian, separate polymeroid biofacies developed in warm waters of the Laurentian openshelf and in cool waters of deeper, outermost shelf to uppermost basin or slope? areas. Most genera and almost all species found in open-shelf lithofacies were endemic to Laurentia. Important exceptions are genera of the Dorypygidae (especially Dorypyge, Kootenia and Olenoides) which are widespread in shelf facies of some tectonic plates that were in low palaeolatitudes. Most genera and species of polymeroids from deeper-water habitats of North Greenland seem to be the same as those from cool, shallow-shelf sites of Baltica or peri-Gondwanan terranes.

The presence of polymeroids of Baltic aspect in Laurentian rocks of Nyeboe Land and Peary Land, North Greenland, has important implications for reconstructing the history of tectonic blocks during the early Palaeozoic. It is evident that the presence of trilobites of Baltic aspect in a suspect terrane attached to a tectonic plate that was in low palaeolatitudes is not sufficient evidence in itself to conclude that the terrane is exotic. An exotic terrane is one that has moved from a distant source and subsequently accreted to another tectonic plate. A native terrane, by comparison, can include deep-shelf, slope or basinal areas adjacent to or on the tectonic plate with which it is now associated. The presence of cool-water trilobites of Baltic aspect in a suspect terrane has been commonly used as evidence of an origin in high latitudes. Some cool-water biofacies, however, are similar to each other regardless of latitude or depth and a suspect terrane containing such trilobites could in fact have an origin either in high latitudes or in deep water of low latitudes.

Cool waters evidently were avenues for the dispersal of some organisms (Taylor \& Forester, 1979). On this account, the degree of taxonomic dissimilarity among coolwater faunas of different regions is not necessarily a function of the palaeogeographic distance between those areas. Thus, conclusions about the latitudinal separation of tectonic blocks during the geological past that are based on differences between warm-water and cool-water biofacies are suspect. Conclusions about palaeolatitude based on faunas and lithofacies from shelf successions are more reliable, but palaeomagnetic evidence remains the best indicator of the original latitudinal positions of terranes.

The presence of mixed assemblages of warm-water and cool-water biofacies in the $P$. atavus Zone of North Greenland illustrates a method by which autochthonous terranes of the outer continental shelf or slope can be identified (Babcock, 1991). Taphonomic, sedimentologic, and stratigraphic evidence needs to be examined before assemblages of mixed aspect can be determined to represent organisms that either lived together or were redeposited as bioclastic debris from ecologically separate biofacies. In addition to improving interpretations of the tectonic history of suspect terranes, study of mixed assemblages in continental shelf and slope environments may help to improve the resolution of biostratigraphic correlations between separate continents.

Acknowledgements. Grateful acknowledgement to the many people and institutions who made this study possible is given in the accompanying paper on polymeroid trilobites (Babcock, 1994) in this volume.

\section{References}

Archer, A. W. \& C. G. Maples. 1987: Monte Carlo simulation of selected binomial similarity coefficients (I): effect of number of variables. Palaios 2, 609-617.

Babcock, L. E. 1990: Biogeography, phylogenetics, and systematics of some Middle Cambrian trilobites from open-shelf to basinal lithofacies of North Greenland and Nevada. Unpublished Ph.D. dissert., Univ. Kansas, 222 pp.

Babcock, L. E. 1991: Debris beds containing mixed faunal representatives from shelf-margin biofacies: a tool for use in terrane analysis. Geol. Soc. Am. Abstr. Prog. 23(3), 2.

Babcock, L. E. 1994: Polymeroid trilobites from the Henson Gletscher and Kap Stanton formations (Middle Cambrian), North Greenland. Bull. Gronlands geol. Unders. 169 (this volume).

Babcock, L. E. \& Robison, R. A. 1989: Paleobiogeographic 
significance of Middle Cambrian trilobites from North Greenland. Geol. Soc. Am. Abstr. Prog. 21(6), A340.

Barnes, C. R. \& Fåhraeus, L. E. 1975: Provinces, communities, and the proposed nektobenthic habit of Ordovician conodontophorids. Lethaia 8, 133-149.

Beebe, M. A. 1989: Unusual preservation of Cambrian trilobites in the Weeks Formation of Utah. Geol. Soc. Am. Abstr. Prog. 21(6), A71.

Benson, R. H. 1975: The origin of the psychrosphere as recorded in changes of deep-sea ostracode assemblages. Lethaia 8, 69-83.

Benson, R. H. 1988: Ostracods and palaeoceanography. In De Decker, P., Colin, J.-P. \& Peypouquet, J.-P. (ed.) Ostracoda in the earth sciences, 1-26. Amsterdam: Elsevier.

Bergström, J. \& Levi-Setti, R. 1978. Phenotypic variation in the Middle Cambrian trilobite Paradoxides davidis Salter at Manuels, SE Newfoundland. Geolog. Palaeont. 12, 1-40.

Bergström, S. M. 1977: Early Paleozoic conodont biostratigraphy in the Atlantic borderlands. In Swain, F. M. (ed.) Stratigraphic micropaleontology of Atlantic basin and borderlands, 85-110. New York: Elsevier.

Bergström, S. M. \& Carnes, J. B. 1976: Conodont biostratigraphy and paleoecology of the Holston Formation (Middle Ordovician) and associated strata in eastern Tennessee. In Barnes, C. R. (ed.) Conodont paleoecology. Spec. Pap. geol. Assoc. Canada 15, 27-57.

Bird, J. M. \& Rasetti, F. 1968: Lower, Middle, and Upper Cambrian faunas in the Taconic sequence of eastern New York: stratigraphic and biogeographic significance. Spec. Pap. geol. Soc. Am. 113, 66 pp.

Bird, J. M. \& Theokritoff, G. 1968: Mode of occurrence of fossils in the Taconic allochthon. Spec. Pap. geol. Soc. Am. 101, 248 only.

Bruun, A. F. 1957: Deep sea and abyssal depths. In Hedgpeth, J. W. (ed.) Treatise on marine ecology and paleoecology, Vol. 1, Ecology. Mem. geol. Soc. Am. 67, 641-672.

Burrett, C. \& Richardson, R. 1980: Trilobite biogeography and Cambrian tectonic models. Tectonophys. 63, 155-192.

Campbell, L. D. 1971: Occurrence of 'Ogygopsis shale' fauna in southeastern Pennsylvania. J. Paleont. 45, 437-440.

Conway Morris, S. \& Rushton, A. W. A. 1988: Precambrian to Tremadoc biotas in the Caledonides. In Harris, A. L. \& Fettes, D. J. (ed.) The Caledonian-Appalachian Orogen. Spec. Publ. geol. Soc. Lond. 38, 93-109.

Cook, H. E. \& Taylor, M. E. 1975: Early Paleozoic continental margin sedimentation, trilobite biofacies, and the thermocline, western United States. Geology 3, 559-562.

Cook, H. E. \& Taylor, M. E. 1977: Comparison of continental slope and shelf environments in the Upper Cambrian and lowest Ordovician of Nevada. In Cook, H. E. \& Enos, P. (ed.) Deep-water carbonate environments. Spec. Publ. Soc. Econ. Paleont. Mineral. 25, 51-81.

Cook, H. E. \& Taylor, M. E. 1989: Evolution of early Paleozoic carbonate seamount, Malyi Karatau Range, southern Kazakhstan, USSR: new evidence for early history of Kazakhstania. Abstr. 28 int. geol. Congr., Washington D.C. 1, 322 only.

Cook, H. E. et al. 1991: Comparison of two early Paleozoic carbonate submarine fans - western United States and south- ern Kazakhstan, Soviet Union. In Cooper, J. D. \& Stevens, C. H. (ed.) Paleozoic paleogeography of the Western United States - II. Pacific section, Soc. Econ. Paleont. Mineral., 847-872.

Cowie, J. W. 1971: Lower Cambrian faunal provinces. In Middlemiss, F. A., Rawson, P. F. \& Newall, G. (ed.) Faunal provinces in space and time. Spec. Publ. geol. Soc. Lond. 4, $31-46$.

Cowie, J. W. 1974: The Cambrian of Spitsbergen and Scotland. In Holland, C. H. (ed.) Lower Palaeozoic rocks of the world, Vol. 2, Cambrian of the British Isles, Norden and Spitsbergen, 125-155. London: J. Wiley \& Sons.

Ekman, S. 1953: Zoogeography of the sea, 417 pp. London: Sidgwick and Jackson.

Fletcher, T. P., Higgins, A. K. \& Peel, J. S. 1988: A BaltoScandian Middle Cambrian fauna from Peary Land, North Greenland. Rapp. Grønlands geol. Unders. 137, 118 only.

Fortey, R. A. 1975: Early Ordovician trilobite communities. Fossils \& Strata 4, 331-352.

Fortey, R. A. \& Cocks, L. R. M. 1986: Marginal faunal belts and their structural implications, with examples from the lower Paleozoic. $J l$ geol. Soc. Lond. 143, 151-160.

Gromet, L. P. 1989: Avalonian terranes and late Paleozoic tectonism in southeastern New England; constraints and problems. In Dallmeyer, R. D. (ed.) Terranes in the circum-Atlantic orogens. Spec. Pap. geol. Soc. Am. 230, 193-211.

Harrington, H. J. et al. 1959: Systematic descriptions. In Moore, R. C. (ed.) Treatise on invertebrate paleontology, part $\mathrm{O}$, Arthropoda 1, 0170-O540. Lawrence: Geol. Soc. Am. and Kansas Univ. Press.

Hart, W. D., Stitt, J. H., Hohensee, S. R. \& Ethington, R. L. 1987: Geological implications of Late Cambrian trilobites from the Collier Shale, Jessieville area, Arkansas. Geology 15, 447-450.

Hazel, J. E. 1970: Binary coefficients and clustering in biostratigraphy. Bull. geol. Soc. Am. 81, 3237-3252.

Hazel, J. E. 1977: Use of certain multivariate and other techniques in assemblage zonal biostratigraphy: examples using Cambrian, Cretaceous, and Tertiary benthic invertebrates. In Kauffman E. G. \& Hazel, J. E. (ed.) Concepts and methods of biostratigraphy, 187-212. Stroudsburg: Dowden, Hutchinson \& Ross.

Hedgpeth, J. W. 1957: Marine biogeography. In Hedgpeth, J. W. (ed.) Treatise on marine ecology and paleoecology, Vol. 1, Ecology. Mem. geol. Soc. Am. 67, 359-382.

Higgins, A. K., Ineson, J. R., Peel, J. S., Surlyk, F. \& Sønderholm, M. 1991: Lower Palaeozoic Franklinian Basin of North Greenland. Bull. Gronlands geol. Unders. 160, 71-139.

Hiscott, R. N. \& James, N. P. 1985: Carbonate debris flows, Cow Head Group, western Newfoundland. J. sed. Petrol. 55, 735-745.

Hohensee, S. R. \& Stitt, J. H. 1989: Redeposited Elvinia Zone (Upper Cambrian) trilobites from the Collier Shale, Ouachita Mountains, west-central Arkansas. J. Paleont. 63, 857-879.

Hood, K. C. \& Robison, R. A. 1988: Trilobite and lithofacies relationships in the Holm Dal Formation (late Middle Cambrian), central North Greenland. Meddr Grønland Geosci. 20, $105-112$. 
Horton, J. W., Jr., Drake, A. A., Jr. \& Rankin, D. W. 1989: Tectonostratigraphic terranes and their Paleozoic boundaries in the central and southern Appalachians. In Dallmeyer, R, D. (ed.) Terranes in the circum-Atlantic orogens. Spec. Pap. geol. Soc. Am. 230, 213-245.

Howell, B. F. 1925: The faunas of the Cambrian Paradoxides beds at Manuels, Newfoundland. Bulls Am. Paleont. 11(43), $140 \mathrm{pp}$.

Howell, B. F. 1937: Cambrian Centropleura vermontensis fauna of northwestern Vermont. Bull. geol. Soc. Am. 48, 11471210.

Hubert, J. F., Suchecki, R. K. \& Callahan, R. K. M. 1977: The Cow Head Breccia: sedimentology of the Cambro-Ordovician continental margin, Newfoundland. In Cook, H. E. \& Enos, P. (ed.) Deep-water carbonate environments. Spec. Publ. Soc. econ. Paleont. Mineral. 25, 125-154.

Hutchinson, R. D. 1952: Middle Cambrian of the Atlantic realm in eastern Gaspé. Am. J. Sci. 250, 275-280.

Hutchinson, R. D. 1962: Cambrian stratigraphy and trilobite faunas of southeastern Newfoundland. Bull. geol. Surv. Canada 88, 156 pp.

Ineson, J. R. 1980: Carbonate debris flows in the Cambrian of south-west Peary Land, eastern North Greenland. Rapp. Grønlands geol. Unders. 99, 43-49.

Ineson, J. R. 1988: Lithostratigraphy and depositional setting of the Holm Dal Formation (Middle Cambrian), central North Greenland. Meddr Grønland Geosci. 20, 9-21.

Ineson, J. R., Surlyk, F., Higgins, A. K. \& Peel, J. S. 1994: Slope apron and deep shelf sediments of the Brønlund Fjord and Tavsens Iskappe Groups (Lower Cambrian - Lower Ordovician) in North Greenland: stratigraphy, facies and depositional setting. Bull. Gronlands geol. Unders. 169 (this volume).

James, N. P. \& Stevens, R. K. 1986: Stratigraphy and correlation of the Cambro-Ordovician Cow Head Group, western Newfoundland. Bull. geol. Surv. Canada 366, $143 \mathrm{pp.}$

Jell, P. A. 1974: Faunal provinces and possible planetary reconstruction of the middle Cambrian. J. Geol. 82, 319-350.

Jell, P. A. 1975: Australian Middle Cambrian eodiscoids with a review of the superfamily. Palaeontographica A 150, 1-97.

Kaesler, R. L. 1966: Quantitative re-evaluation of ecology and distribution of recent Foraminifera and Ostracoda of Todos Santos Bay, Baja California, Mexico. Paleont. Contr. Univ. Kansas Pap. 10, 1-50.

Keppie, J. D. 1989: Northern Appalachian terranes and their accretionary history. In Dallmeyer, R. D. (ed.) Terranes in the circum-Atlantic orogens. Spec. Pap. geol. soc. Am. 230, 159 192.

Kindle, C. H. 1982: The C. H. Kindle collection: Middle Cambrian to Lower Ordovician trilobites from the Cow Head Group, western Newfoundland. Pap. geol. Surv. Can. 82-1C, 1-17.

Kruskal, J. B. 1964a: Multidimensional scaling by optimizing goodness of fit to a nonmetric hypothesis. Psychometrika 29, $1-27$.

Kruskal, J. B. 1964b: Nonmetric multidimensional scaling: a numerical method. Psychometrica 29, 28-42.
Lochman-Balk, C. \& Wilson, J. L. 1958: Cambrian biostratigraphy in North America. J. Paleont. 32, 312-350.

Ludvigsen, R. 1978: Middle Ordovician trilobite biofacies, southern Mackenzie Mountains. Spec. Pap. geol. Assoc. Can. 18, 1-37.

Maples, C. G. \& Archer, A. W. 1988: Monte Carlo simulation of selected binomial similarity coefficients (II): effect of sparse data. Palaios 3, 95-103.

McKerrow, W. S. \& Cocks, L. R. M. 1976: Progressive faunal migration across the Iapetus Ocean. Nature 263, 304-306.

McLaughlin, K. P. \& Enbysk, B. B. 1950: Middle Cambrian trilobites from Pend Oreille County, Washington. J. Paleont. 24, 466-471.

Menzies, R. J., George, R. Y. \& Rowe, G. T. 1973: Abyssal environment and ecology of the world oceans, $488 \mathrm{pp}$. New York: Wiley-Interscience.

Nelson, C. A. 1963: Stratigraphic range of Ogygopsis. J. Paleont. 37, 244-248.

Öpik, A. A. 1979: Middle Cambrian agnostids: systematics and biostratigraphy. Bull. Bur. Miner. Resour. Austral. 172; vol. 1, 188 pp.; vol 2, 67 pls.

Palmer, A. R. 1969: Cambrian trilobite distributions in North America and their bearing on Cambrian paleogeography in Newfoundland. In Kay, M. (ed.) North Atlantic-geology and continental drift. Mem. Am. Assoc. petrol. Geol. 12, 139-148.

Palmer, A. R. 1972: Problems of Cambrian biogeography. Proc. 24 int. geol. Congr., Montreal 7, 310-315.

Palmer, A. R. 1973: Cambrian trilobites. In Hallam, A. (ed.) Atlas of palaeogeography, 3-11. Amsterdam: Elsevier.

Palmer, A. R. 1979: Cambrian. In Robison, R. A. \& Teichert, C. (ed.) Treatise on invertebrate paleontology, part A, biogeography and biostratigraphy, A119-A135. Lawrence: Geol. Soc. Am. \& Kansas Univ. Press.

Palmer, A. R. \& Halley, R. B. 1979: Physical stratigraphy and trilobite biostratigraphy of the Carrara Formation (Lower and Middle Cambrian) in the southern Great Basin. Prof. Pap. U.S. geol. Surv. 1047, 1-131.

Palmer, A. R. \& Peel, J. S. 1981: Dresbachian trilobites and stratigraphy of the Cass Fjord Formation, western North Greenland. Bull. Gronlands geol. Unders. 141, 46 pp.

Palmer, A. R. \& Stewart, J. S. 1968: A paradoxidid trilobite from Nevada. J. Paleont. 42, 177-179.

Peel, J. S. (ed.) 1988: Stratigraphy and palaeontology of the Holm Dal Formation (late Middle Cambrian), central North Greenland. Meddr Gronland Geosci. 20, 168 pp.

Poulsen, C. 1927: The Cambrian, Ozarkian and Canadian faunas of northwest Greenland. Meddr Grønland 70, 233-343.

Poulsen, C. 1960: Fossils from the late Middle Cambrian Bolaspidella Zone of Mendoza, Argentina. Mat.-Fys. Medd. Danske Vid. Selsk. 32, 42 pp.

Poulsen, V. 1964: Contribution to the Lower and Middle Cambrian paleontology and stratigraphy of northwest Greenland. Meddr Gronland 164(6), 105 pp.

Poulsen, V. 1969: An Atlantic Middle Cambrian fauna from North Greenland. Lethaia 2, 1-14.

Poulseri, V. \& Anderson, M. M. 1975: The Middle-Upper Cambrian transition in southeastern Newfoundland, Canada. Can. J. Earth Sci. 12, 2065-2079. 
Ramos, V. A., Jordan, T. E., Allmendinger, R. W., Mpodozis, C., Kay, S. M., Cortes, J. M. \& Palma, A. 1986: Paleozoic terranes of the central Argentine-Chilean Andes. Tectonics 5, $855-880$.

Rasetti, F. 1951: Middle Cambrian stratigraphy and faunas of the Canadian Rocky Mountains. Smithson. misc. Collns 116 (5), $277 \mathrm{pp}$

Rasetti, F. 1967: Lower and Middle Cambrian trilobite faunas from the Taconic sequence of New York. Smithson. misc. Collns 152(4), $111 \mathrm{pp}$.

Robison, R. A. 1964: Late Middle Cambrian faunas from western Utah. J. Paleont. 38, 510-566.

Robison, R. A. 1972: Mode of life of agnostid trilobites. Proc. 24 int. geol. Congr., Montreal 7, 33-40.

Robison, R. A. 1976: Middle Cambrian trilobite biostratigraphy of the Great Basin. Brigham Young Univ. geol. Stud. 23(2), 93-109.

Robison, R. A. 1984: Cambrian Agnostida of North America and Greenland, Part I, Ptychagnostidae. Paleontol. Contr. Univ. Kansas Pap. 109, 59 pp.

Robison, R. A. 1988: Trilobites of the Holm Dal Formation (late Middle Cambrian), central North Greenland. Meddr Grønland Geosci. 20, 23-103.

Robison, R. A. 1991: Cambrian period. In Goetz, P. W. (ed.) The new Encyclopaedia Brittanica, 785-792. (15th edit.). Vol. 19. Macropaedia. Chicago.

Robison, R. A. 1994: Agnostoid trilobites from the Henson Gletscher and Kap Stanton formations (Middle Cambrian), North Greenland. Bull. Gronlands geol. Unders. 169 (this volume)

Robison, R. A. \& Babcock, L. E. 1990: Biogeography of Middle Cambrian trilobites from North Greenland: implications for terrane analysis. 3 int. Symp. Cambrian System, Novosibirsk, USSR, Abstr. 151.

Rushton, A. W. A. 1978: Fossils from the Middle-Upper Cambrian transition beds in the Nuneaton district. Palaeontology 21, 245-283

Samson, S., Palmer, A. R., Robison, R. A. \& Secor, D. T., Jr. 1990: Biogeographical significance of Cambrian trilobites from the Carolina slate belt. Bull. geol. Soc. Am. 102, 1459 1470.

Scotese, C. R. 1987: Phanerozoic plate tectonic reconstructions. Paleoceanogr. map. Proj., Univ. Texas, Inst. Geophys., Tech. Rept 40, 54 pp.

Scotese, C. R., Bambach, R. K., Barton, C., Van der Voo, R. \& Ziegler, A. M. 1979: Paleozoic base maps. J. Geol. 87, 217277.

Scotese, C. R. \& Denham, C. R. 1988: User's manual for Terra Mobilis: plate tectonics for the Macintosh, 43 pp. Houston: Earth in Motion Technologies.

Scotese, C. R. \& McKerrow, W. S. 1990: Revised world maps and introduction. In McKerrow, W. S. \& Scotese, C. R. (ed.) Palaeozoic palaeogeography and biogeography. Mem. geol. Soc. Lond. 12, 1-21.

Secor, D. T., Jr., Samson, S. L., Snoke, A. W. \& Palmer, A. R. 1983: Confirmation of the Carolina slate belt as an exotic terrane. Science 221, 649-650.

Shah, S. K. \& Sudan, C. S. 1982: Bolaspidella from the Cam- brian of Kashmir and its stratigraphic significance. $J$. geol. Soc. India 23, 236-245.

Shaw, A. B. 1966: Paleontology of northwestern Vermont. XI. Fossils from the Middle Cambrian St. Albans Shale. J. Paleont. 40, 843-858.

Shergold, J. H. 1988: Review of trilobite biofacies distributions at the Cambrian-Ordovician boundary. Geol. Mag. 125, 363380 .

Skevington, D. 1974: Controls influencing the composition and distribution of Ordovician graptolite faunal provinces. Spec. Pap. Palaeontology 13, 59-73.

Smith, A. G., Hurley, A. M. \& Briden, J. C. 1981: Phanerozoic paleocontinental world maps, 102 pp. New York: Cambridge Univ. Press.

Sneath, P. H. A. \& McKenzie, K. G. 1973: Statistical methods for the study of biogeography. Spec. Pap. Palaeontology 12 $1-42$.

Staff, G. M., Stanton, R. J., Jr., Powell, E. N. \& Cummins, H. 1986: Time-averaging, taphonomy, and their impact on paleocommunity reconstruction: death assemblages in Texas bays. Bull. geol. Soc. Am. 97, 428-443.

Stewart, J. H. \& Palmer, A. R. 1967: Callaghan window - a newly discovered part of the Roberts thrust, Toiyabe Range, Lander County, Nevada. Prof. Pap. U.S. geol. Surv. 575D, D56-D63.

Surlyk, F. 1991: Tectonostratigraphy of North Greenland. Bull. Grønlands geol. Unders. 160, 25-47.

Sweet, W. C. \& Bergström, S. M. 1974: Provincialism exhibited by Ordovician conodont faunas. In Ross, C. A. (ed.) Paleogeographic provinces and provinciality. Soc. econ. Paleontol. Mineral. Spec. Publ. 21, 189-202.

SYSTAT, Inc. 1986: SYSTAT: the system for statistics.

Taylor, M. E. 1976: Indigenous and redeposited trilobites from Late Cambrian basinal environments of central Nevada. $J$. Paleont. 50, 668-700.

Taylor, M. E. 1977: Late Cambrian of western North America: trilobite biofacies, environmental significance, and biostratigraphic implications. In Kauffman, E. G. \& Hazel, J. E. (ed.) Concepts and methods of biostratigraphy, 397-425. Stroudsburg: Dowden, Hutchinson \& Ross, Inc.

Taylor, M. E. \& Cook, H. E. 1976: Continental shelf and slope facies in the Upper Cambrian and lowest Ordovician of Nevada. Brigham Young Univ. geol. Stud. 23(2), 181-214.

Taylor, M. E. \& Forester, R. M. 1979: Distributional model for marine isopod crustaceans and its bearing on early Paleozoic paleozoogeography and continental drift. Bull. geol. Soc. Am. 90, 405-413.

Theokritoff, G. 1979: Early Cambrian provincialism and biogeographic boundaries in the North Atlantic region. Lethaia 12 281-295.

Theokritoff, G. 1985: Early Cambrian biogeography in the North Atlantic region. Lethaia 18, 283-293.

Thomas, A. T., Owens, R. M. \& Rushton, A. W. A. 1984: Trilobites in British stratigraphy. Spec. Rept geol. Soc. Lond. 16, $78 \mathrm{pp}$.

Torsvik, T. H., Ryan, P. D., Trench, A. \& Harper, D. A. T. 1991: Cambrian-Ordovician paleogeography of Baltica. Geology 19, 7-10. 
Ulrich, E. O. \& Schuchert, C. 1902: Paleozoic seas and barriers in eastern North America. Bull. N.Y. State Mus. 52, 633-663.

Valentine, J. W. 1973: Evolutionary paleoecology of the marine biosphere, 511 pp. New Jersey: Prentice-Hall.

Westergård, A. H. 1946: Agnostidea of the Middle Cambrian of Sweden. Sver. geol. Unders. C 477, 141 pp.

Westergård, A. H. 1953: Non-agnostidean trilobites of the Middle Cambrian of Sweden III. Sver. geol. Unders. C 526, 59 pp.

Williams, H. \& Hatcher, R. D., Jr. 1982: Suspect terranes and accretionary history of the Appalachian orogen. Geology 10 , 530-536.

Wilson, J. T. 1966: Did the Atlantic close and then reopen? Nature 211, 676-681.

Young, G. A. \& Ludvigsen, R. 1989: Mid-Cambrian trilobites from the lowest part of the Cow Head Group, western Newfoundland. Bull. geol. Surv. Can. 392, 49 pp.

Young, G. C. 1986: Cladistic methods in Paleozoic reconstruction. J. Geol. 94, 523-537. 